Review

\title{
Opportunities and Challenges of Renewable Energy Production in Ethiopia
}

\author{
Girum Ayalneh Tiruye ${ }^{1, *(\mathbb{C})}$, Abreham Tesfaye Besha ${ }^{2}$, Yedilfana Setarge Mekonnen $\left.{ }^{3} \mathbb{(}\right)$, Natei Ermias Benti ${ }^{3,+} \mathbb{C}^{\mathbb{D}}$, \\ Gebrehiwet Abrham Gebreslase ${ }^{4,5}$ and Ramato Ashu Tufa ${ }^{6, *}$ (D)
}

1 Materials Science Program, Department of Chemistry, College of Natural and Computational Sciences, Addis Ababa University, Addis Ababa P.O. Box 1176, Ethiopia

2 Department of Chemistry, College of Natural and Computational Sciences, Jigiiga University, Jigjiga P.O. Box 1020, Ethiopia; abrehamtesfaye396@gmail.com

3 Center for Environmental Science, College of Natural and Computational Sciences, Addis Ababa University, Addis Ababa P.O. Box 1176, Ethiopia; yedilfana.setarge@aau.edu.et (Y.S.M.); natei.ermias@aau.edu.et (N.E.B.)

4 Department of Chemical Engineering, Mekelle Institute of Technology-Mekelle University (MIT-MU), Mekelle P.O. Box. 1632, Ethiopia; gebrehiwet14@gmail.com

5 Instituto de Carboquímica, ICB-CSIC, C/Miguel Luesma Castán, 4, 50018 Zaragoza, Spain

6 Department of Energy Conversion and Storage, Technical University of Denmark, Building 310, 2800 Kgs. Lyngby, Denmark

* Correspondence: girum.ayalneh@aau.edu.et (G.A.T.); rastu@dtu.dk or rashtey@gmail.com (R.A.T.)

+ Current Address: Department of Physics, College of Natural and Computational Sciences, Wolaita Sodo University, Wolaita Sodo P.O. Box 138, Ethiopia.

Citation: Tiruye, G.A.; Besha, A.T.; Mekonnen, Y.S.; Benti, N.E.;

Gebreslase, G.A.; Tufa, R.A.

Opportunities and Challenges of

Renewable Energy Production in Ethiopia. Sustainability 2021, 13, 10381. https://doi.org/10.3390/

su131810381

Academic Editor:

George Kyriakarakos

Received: 30 July 2021

Accepted: 10 September 2021

Published: 17 September 2021

Publisher's Note: MDPI stays neutral with regard to jurisdictional claims in published maps and institutional affiliations.

Copyright: (c) 2021 by the authors. Licensee MDPI, Basel, Switzerland. This article is an open access article distributed under the terms and conditions of the Creative Commons Attribution (CC BY) license (https:// creativecommons.org/licenses/by/ $4.0 /)$.

\begin{abstract}
Ethiopia is one of the fastest-growing economies in the world despite immense challenges towards access to sustainable energy supplies and modern energy technologies. The country is undertaking great effort towards the development of renewable energy technologies and green legacy. However, the largest share of energy consumption $(\approx 87 \%)$ in Ethiopia is dominated by traditional fuels (charcoal, fuel wood, dung cakes, and agricultural residues) which pose various health and environmental risks. The country has an enormous amount of renewable energy potentials (e.g., solar, hydro, wind and geothermal), but only $5 \%$ of its full hydropower potential is exploited and others are not fully harvested or not well developed to date. This review paper provides a comprehensive assessment on renewable energy availability, potential, opportunity, and challenges in Ethiopia. We believe the information provided in this review will enlighten the current and future prospects of renewable energy deployment in Ethiopia.
\end{abstract}

Keywords: renewable energy; Ethiopia; solar; wind; hydro; biomass; geothermal; solid waste

\section{Introduction}

With the growth of population and industrialization, the global energy demand is increasing at an unprecedented rate. Although the development of renewable energy technologies is growing rapidly nowadays, the largest portion of the energy market is dominated by fossil fuels [1], which is strictly related to the emission of greenhouse gases (GHG) and climate change. However, the forecast on the trend of primary energy sources indicate that renewable energy is the fastest-growing energy source in the coming two decades [2,3]. Subsequently, it helps to deter GHG emissions, ensuring reliable and affordable energy. The World's net electricity generation is expected to increase by $69 \%$ from 21.6 trillion $\mathrm{kWh}$ in 2012 to 36.5 trillion $\mathrm{kWh}$ in 2040 out of which renewable energy sources will contribute 11 trillion $\mathrm{kWh}$ [2].

Africa, as one of the fastest growing continents in the world, faces a massive challenge related to energy issues in the coming years. By 2030, more than 600 million people in subSaharan Africa will live without access to reliable electricity, and the rest largely depend on traditional energy sources [4]. Ethiopia is one of the fastest growing economies in Africa; 
however, its access to modern energy supplies is one of the lowest in the World. The Government of Ethiopia (GoE) has been taking renewable energy initiatives and efforts to respond to the ever-increasing demand for electricity in the country and to combat climate change. The 2017 agreement between the GoE and the Italian Enel, a multinational electricity corporation is one of the initiatives that was signed bilaterally [5]. The agreement seeks to exploit and use the vast renewable energy resources of the country. Ethiopia has an abundant source of solar irradiations in the highlands, wind energy in flat areas, and several rivers in forested areas. However, these ample energy sources are largely unexploited. Biomass is regarded as the major energy sources in Ethiopia accounting for $87 \%$ of the total energy supply [6]. Nevertheless, there are large variations on the current energy systems in rural and urban areas. Almost all rural area's households depend on traditional fuels for cooking whereas about $90 \%$ of urban populations use electricity for lightning.

Despite its large dependence on traditional energy sources, the country is gradually moving forward to reducing its reliance on non-renewable energy sources and shift the power to a clean and renewable energy supply. Currently, energy demand is increasing at an alarming rate due to the fast-growing economy and flourishing infrastructures [6]. Therefore, finding an alternative energy source to overcome the problems associated with the traditional energy source could then be advocated at its best.

This review paper provides a comprehensive assessment of renewable energy sources in Ethiopia, along with remarks on renewable energy availability, potential, opportunity, and challenges. The review also discusses the current and future prospect of renewable energy deployment in Ethiopia. Moreover, it provides information on the potential emerging energy systems based on marine renewable energy sources and hydrogen technologies in the country.

\section{Current Energy Sources in Ethiopia}

Ethiopia is one of the energy deficient countries in the world with a net energy importer. The country is potentially endowed with various potential sources of renewable energy. It has the not fully exploited potential of renewable energy up to 45,000 MW from hydropower, 10,000 MW from wind, $5000 \mathrm{MW}$ from geothermal and an average of $5.26 \mathrm{kWh}$ per square meter per day from solar energy [7]. Except for the biomass fuel, most of the presented energy source is either untapped or not fully developed. For example, in terms of hydropower potential, Ethiopia is ranked second in Africa next to the Democratic Republic of Congo (DRC), but has exploited only $<10 \%$ of its full potential. Despite limited electricity access to its citizen, Ethiopia is one of the countries in sub-Saharan as a hub of renewable resources potential [8]. Table 1 presents some data on the exploitable potential of various energy resources in Ethiopia.

Table 1. Domestic energy source potentials and exploited status in Ethiopia [7,9-13].

\begin{tabular}{|c|c|c|c|c|}
\hline No. & Resorce & Unit & Potential & Exploited \\
\hline 1 & Biomass & $\begin{array}{l}\text { Million metric } \\
\text { ton/year }\end{array}$ & 75 & $<50 \%$ \\
\hline 2 & Hydropower & MW & 45,000 & $<10 \%$ \\
\hline 3 & Solar & $\mathrm{kWh} / \mathrm{m}^{2} /$ day & $5-6$ & $<1 \%$ \\
\hline 4 & Wind & MW & 10,000 & $<1 \%$ \\
\hline 5 & Geothermal & MW & 10,000 & $<1 \%$ \\
\hline 6 & Natural Gas & Billion cubic meter & 113 & $0 \%$ \\
\hline 7 & Coal & Million tone & 300 & $0 \%$ \\
\hline 8 & Oil-shale & Million tone & 253 & $0 \%$ \\
\hline 9 & Firewood & Million tone & 1120 & $30 \%$ \\
\hline 10 & Agricultural waste & Million tone & $15-20$ & $30 \%$ \\
\hline
\end{tabular}


Ethiopia, like many African countries, is heavily reliant on biomass-based energy by consumers for household purposes. The largest energy supply comes from waste and biomass covering up to $92.2 \%$ share of the total primary energy supply followed by oil $(5.7 \%)$ and hydropower (1.6\%) (Figure 1) [14]. The rural area is suffering from the lack of access to electricity with the rate being $32 \%$ coverage, compared to the urban area with $92 \%$ connection to electricity. In Ethiopia, $55.2 \%$ of population is living without access to electricity in $2019[15,16]$. The GoE is striving to enhance electricity access across the country from $45 \%$ in 2018 to $100 \%$ by 2030, with an increasing rate of access $1.7 \%$ annually from 2010-2019 [17,18].

Hydro $1.6 \%$

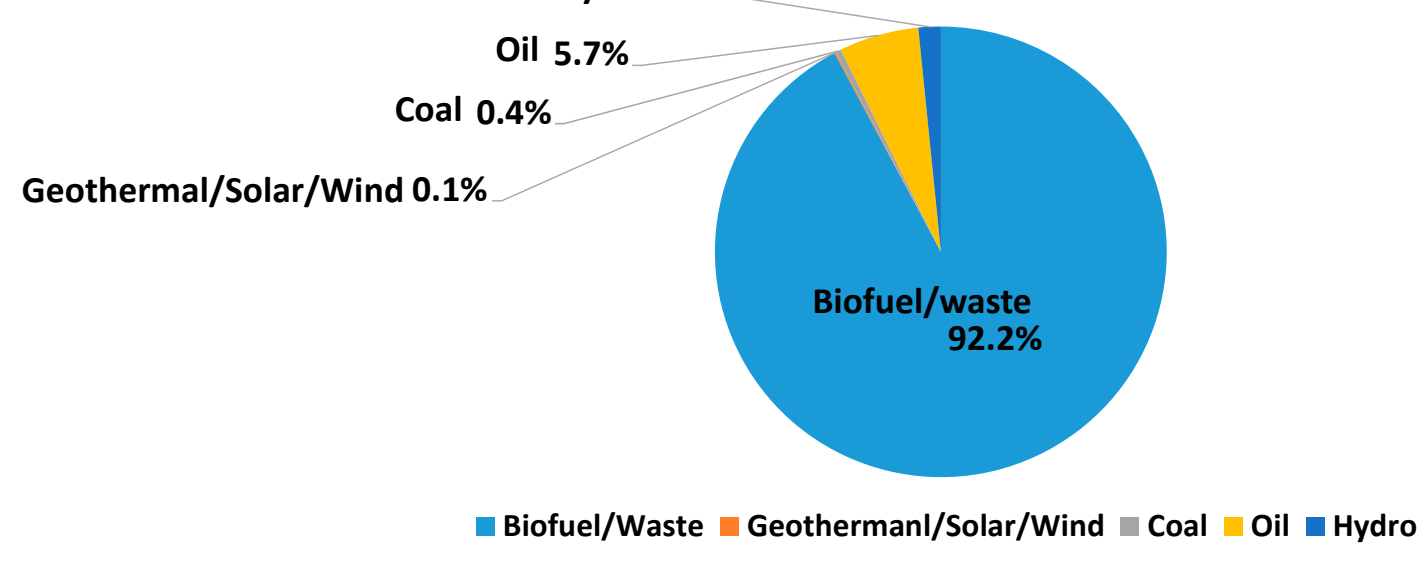

Figure 1. Share of total primary energy supply in Ethiopia as of 2015 [15].

\section{Energy Consumption in Ethiopia}

Biomass energy sources are the main and primary sources of energy consumption in Ethiopia. Traditional fuels (charcoal, fuel wood, dung cakes and agricultural residues) reached about $87 \%$ of the total energy sources as of 2017 . Due to the limited access to national electricity, people in the rural areas use fuel wood and tree residues as a predominant source of lighting and cooking. On the other hand, modern fuels shared approximately $13 \%$ of total energy consumed in 2017, of which, $80 \%$ is covered by hydrocarbon products (light petroleum products $25 \%$ and heavy petroleum products $47 \%$ and coal $8 \%$ ) and $15 \%$ electricity [19].

According to the government report, the total energy requirement of the country increased slightly by $4 \%$ from 39,701 ktoe in 2016 to 41,461 ktoe in 2017. The total energy consumption by all sectors of the economy in 2017 is 38,964 ktoeof which, 3\% (1227 ktoe) light petroleum products (MGR, LFO, Jet fuel, LPG, ethanol and kerosene), 6\% (2292 ktoe) heavy petroleum products (ADO and HFO), 2\% (375 ktoe) hard coal, 2\% (738 ktoe) electricity and $88 \%(34,085$ ktoe) biomass (Figure 2) [19].

The household sector is a major energy consuming sector accounted for $88.2 \%$ followed by the transport sector with $8.4 \%$. The household energy use was predominantly originated from biomass, which accounts for $88 \%$ and $9.26 \%$ was consumed by electricity and petroleum products collectively. Transportation sector energy use was petroleum fuels $82.97 \%$, and bioethanol $17.03 \%$ (Figure 3). Industry, construction and service sectors consumed the remaining (Figure 3). 

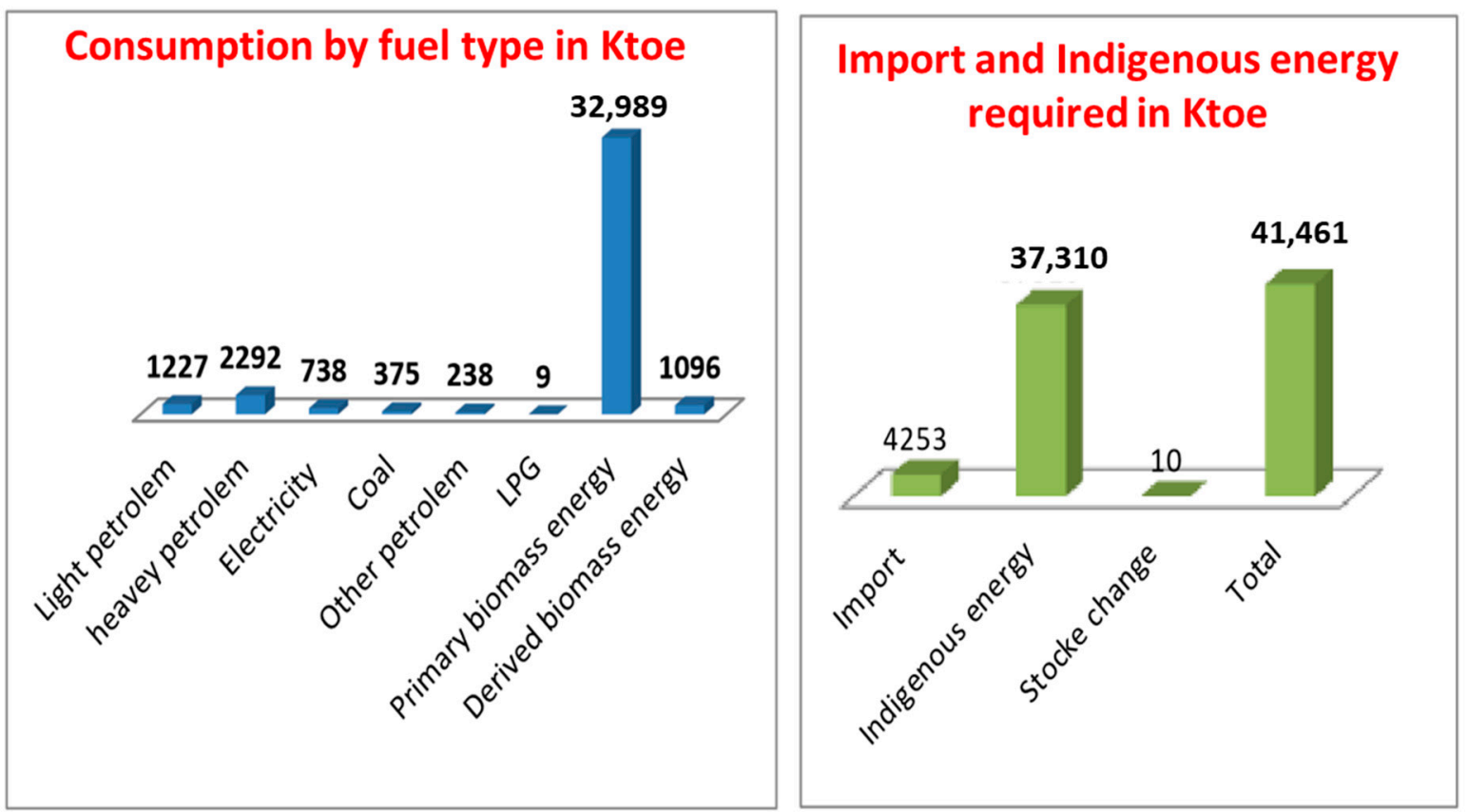

Figure 2. Ethiopia energy consumption by fuel type and energy required [19].

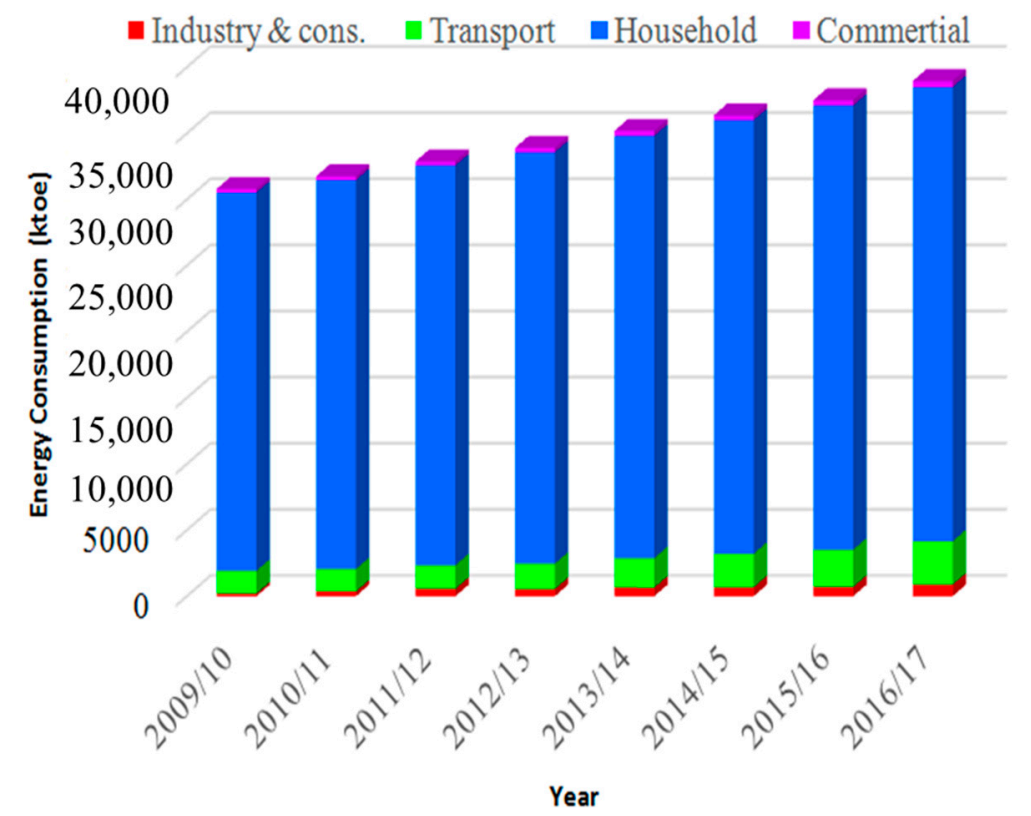

Figure 3. Ethiopia Total energy consumption by sector between 2009/10-2016/17 [19].

\section{Energy Demand and Electrification Rate in Ethiopia}

Ethiopia is gifted with significant renewable energy resources, with huge potential of hydro, solar, wind, bio and geothermal power. It is one of the few countries in subSaharan Africa, if not the world, which generates more than $90 \%$ of its electricity from renewable resources. The existing total electricity generation capacity installed in Ethiopia is about 4244.67 MW [9], of which hydropower takes the lion's share. However, there are great discrepancies in the coverage of electricity access in urban and rural areas $[16,17]$. This indicates that the majority of the population $(>75 \%)$ in the country is living without electricity access. However, the trend shows electrification rate mostly carried out by the GoE is increased from 5\% in 2000 to $45 \%$ in 2016, resulting in the flourishing off-grid access in the rural area (Figure 4a) [20]. Ongoing and future expansion of generation capacity will 
continue to rely exclusively on renewable resources. Given the expected strong growth in demand for electricity (nearly 10\%, annually as shown in Figure 4 b), complementary energy resources must be developed to mitigate the risk of overreliance on and variability of hydropower [21].
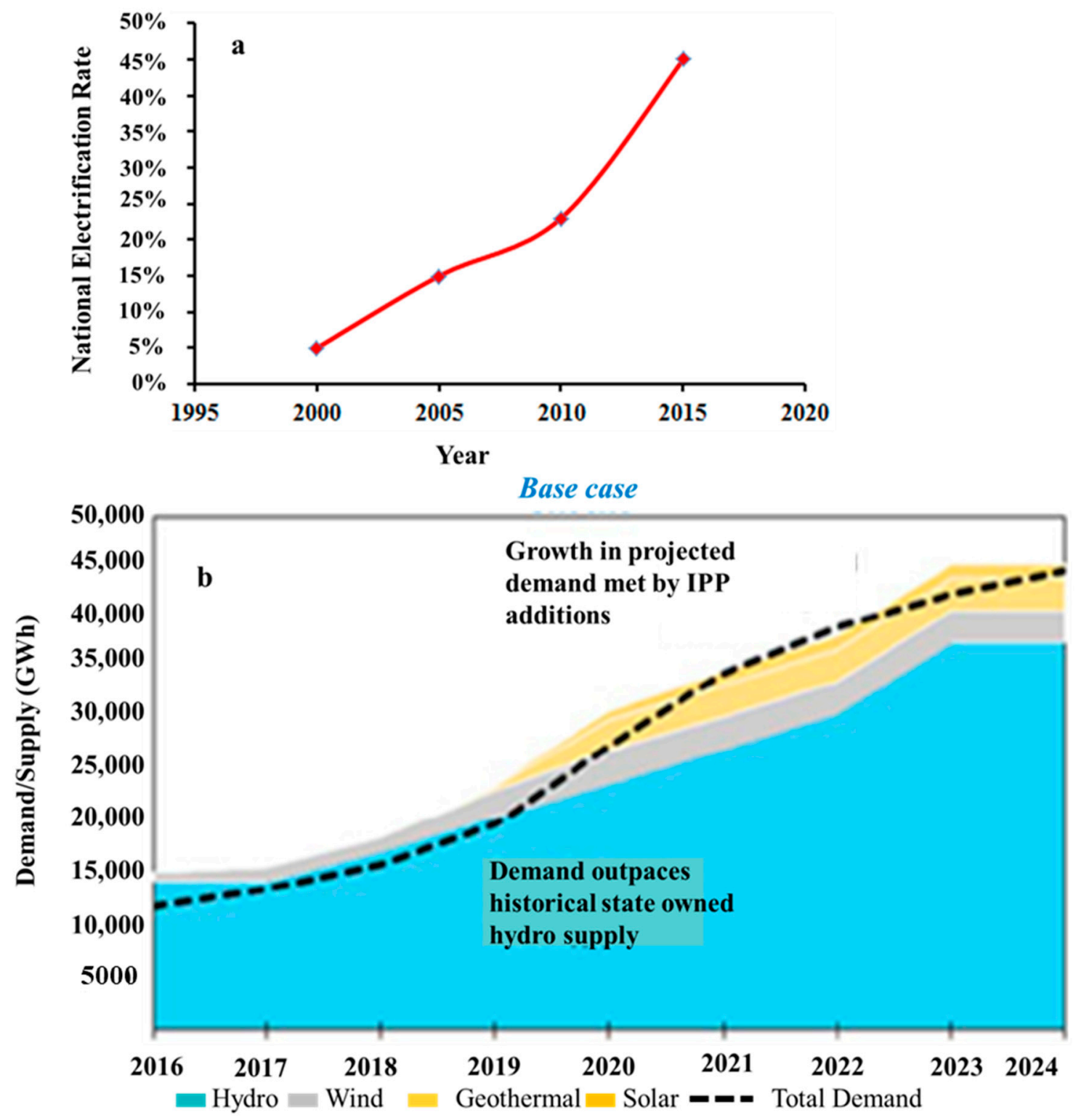

Source: World Bank estimates based on available information on progress of various projects

Figure 4. (a) The progress of national electrification rate in Ethiopia [19], (b) prediction of electricity supply-demand balance in Ethiopia (2016-2024) [20].

For the last two decades, the Ethiopian government has strived to construct a considerable number of megaprojects on renewable energy sources such as hydropower, wind, and solar [8], despite its slow progress and inefficient plan. However, Ethiopia's energy system has neither developed synchronically with the growth of its economy nor with its fast rate of urbanization and speculated future energy demand. The Ethiopian electricity demand by different sectors will also increase exponentially. As can be seen from Figure 5, the electricity demand for industry and domestic will be increased by $46 \%$ and $18 \%$, respectively [8]. 


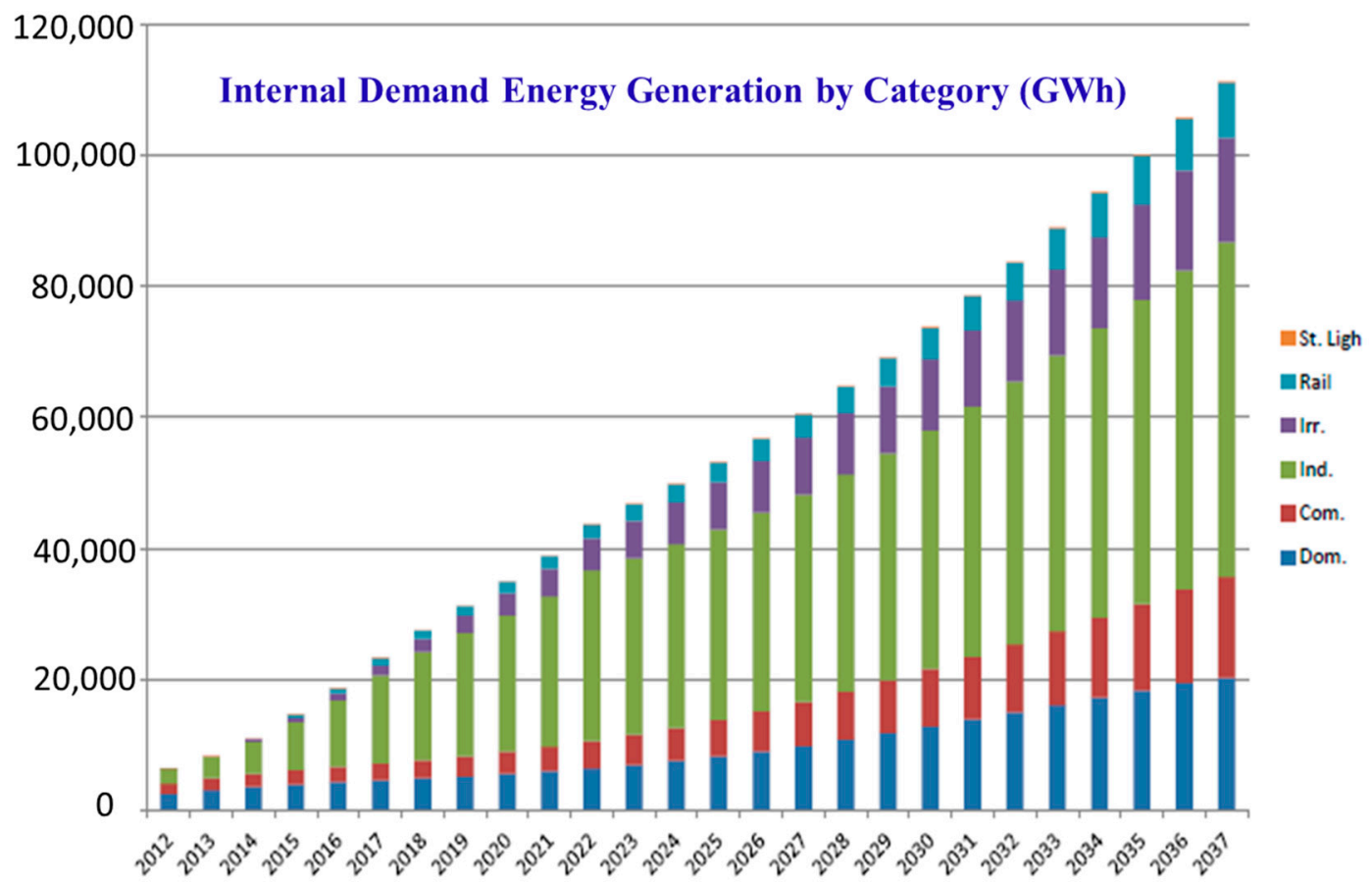

Figure 5. Ethiopian energy demand forecast in different sectors [8].

\section{National Energy Policy Framework in Ethiopia}

Ethiopia has a proactive program to reduce $\mathrm{CO}_{2}$ emissions and affirming the development of renewable energy. Since Ethiopia's energy consumption is mainly based on traditional energy sources, the government has involved a remarkable initiative under different policies related to energy production, deployment, and electrification for the last two decades. Major emphasis was dedicated to hydropower, solar and wind energy resources [22]. The overall goal of the national policies and strategies of the energy sector in Ethiopia is to improve and promote national efforts focusing on efficiency, equitable and optimum dissemination and utilization of the available energy resourcefor substantial socio-economic development and to foster its economic growth [23].

Since 2010, the GoE formulated a comprehensive national policy which is called the Growth and Transformation Plan (GTP-I and GTP-II), in which energy policy is the main part of the plan $[24,25]$. The GTP-1 (2010-2014) and GTP-II (2015-2020), each represents five years of a short-term national plan that includes energy policies. The main objectives of energy policy involve ensuring a reliable supply of energy, encouraging a remarkable shift from the traditional energy source to a modern energy source, and give priority to the development and dissemination of indigenous energy resources. In the GTP-II plan, the energy policy includes the generation of energy from different renewable sources is depicted in Figure 6, even though the current total amount of energy production is much less than the predicted amount for $2019[9,25]$. 


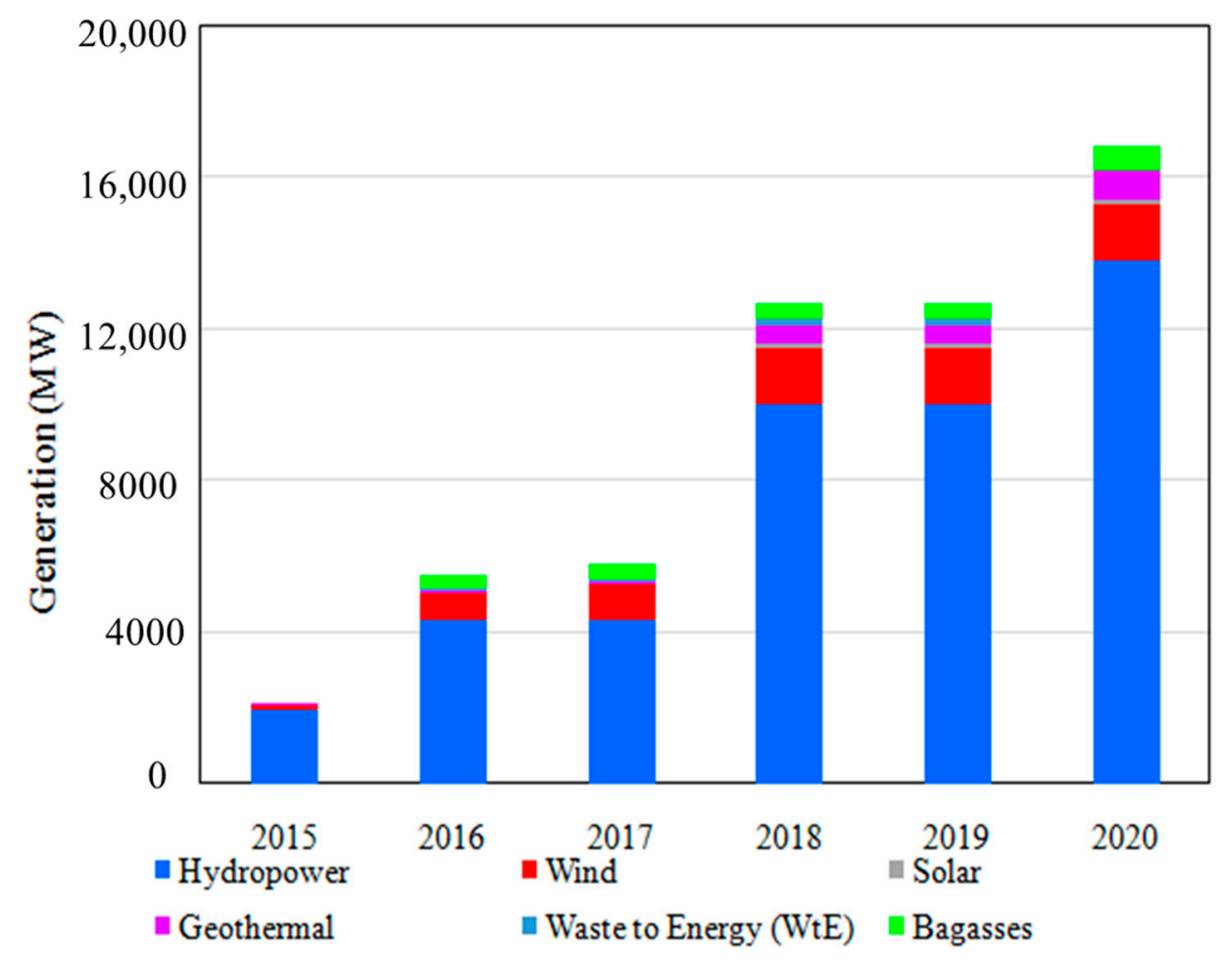

Figure 6. Second Growth and Transformation plan (GTP-II) of energy sector in Ethiopia [9,25].

In the ten years perspective developmental current national plan also called "Ethiopia 2030: The Pathway to Prosperity (2021-2030), the energy sector is included as one of the strategic areas to build climate resilient green economy by 2030. The focus areas of energy in the current national 10 years perspective developmental plan include equity in access to electricity services, energy access and quality, alternative sources of energy, reliability of electricity infrastructure, investment, and income in the energy subsector [26].

\section{Developed and Ongoing Renewable Energy Projects in Ethiopia}

Ethiopia is one of the fast-urbanizing countries in the world and has achieved a profound transformation of the living standard of its citizen for the last two decades. Urbanization ameliorates the quality of life of people while boosting economic growth, but it also dramatically increases the energy consumption which leads to energy crisis. Many cities have been involved in lifting millions of people out of poverty. On the contrary, the cities are becoming the hub of a lot of wastes due to a dramatic transformation. With the rapid population growth and increased consumption, waste has become problematic more than ever in terms of managing and retreating [1]. Recently, Koshe (sometimes called Reppie) which is a place found near the capital city of Ethiopia, Addis Ababa, consists of mountains of urban waste. Since March 2017, there was a shocking circumstance in this place, where a massive landslide of the largest rubbish dump caused to kill more than 100 people [27]. Despite the persistent challenges, the GoE has implemented broader policies and strategies to combat the problem associated with urban pollution and at the same time generate energy from waste to meet the energy demand in the country. For instance, the Reppie waste to energy plant (Figure 7), Africa's first major waste to energy power plant, was opened to produce renewable energy from the waste. The principle is rubbish is burned in a combustion reactor and the emitted heat is used to produce steam water that drives a turbine generator to generate electricity. It was built by Cambridge Industries Limited (CIL), British \& Island with Chinese partner contractors and Danish consultants. 


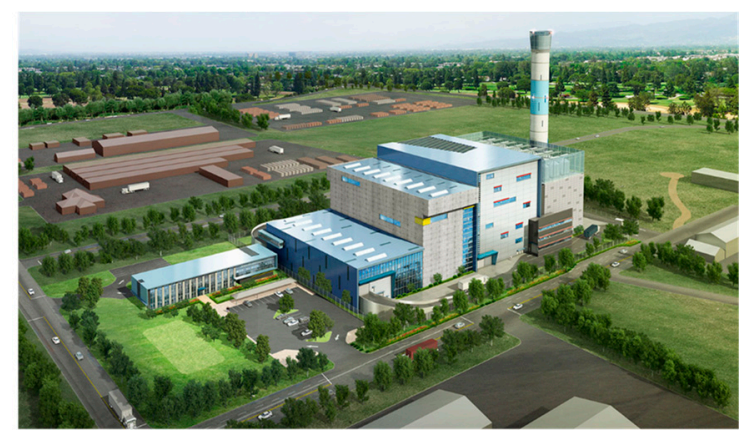

Figure 7. Reppie African's first Waste to Energy plant was found in Addis Ababa, Ethiopia [28,29].

There are also ongoing solar power projects in different parts of Ethiopia for solar electricity generation mainly used in the rural parts as an off-grid energy source. Ethiopia is also installing grid connected photovoltaic (PV)with the capacity of $100 \mathrm{MW}$ near the town of Metehara [13,30]. Additionally, an agreement was signed between the Ethiopian government and the Saudi Arabia Acwa power to scale up a Gad Phase in the Somali region and Dicheto Phase I in the Afar region solar power plant to $250 \mathrm{MW}[13,30]$. Tekeze dam is also one of the mega-projects built by the GoE. This power plant has the capacity to generate up to $300 \mathrm{MW}$ of electricity. During the time of completion, Tekezé Dam was the largest of Africa's arch dam [31]. Gilgel Gibe I, II, and III at Omo River with a capacity of $184 \mathrm{MW}, 420 \mathrm{MW}$ and $1870 \mathrm{MW}$, respectively, are other electrical power development projects in the past. All those hydropower plants produce electricity that is both renewable and dispatch-able [32-34].

Currently, Ethiopia is constructing one of the largest ever engineering projects, the Great Ethiopian Renaissance Dam (GERD) on the Blue Nile River which Ethiopia shares more than $80 \%$ of the water. The dam will be the largest hydropower in Africa and one of the biggest hydropower in the world. The GERD has a huge potential for renewable energy that could solve not only Ethiopia's energy demand but also the neighboring countries. It will provide adequate and cheap electricity to different sectors like manufacturing, transportation, and grid-power supply. The project was started in April 2011 with a running cost of 4.5 billion U.S. dollars. When completed, it is expected to have a reservoir of 74 billion $\mathrm{m}^{3}$ of water and a power capacity of $5150 \mathrm{MW}$. Now, about $80 \%$ of the project is completed [35-38].

\section{Available Renewable Energy Sources in Ethiopia}

Ethiopia has abundant renewable energy resources and has the potential to generate over 60,000 MW of electric power only from hydropower, wind, geothermal and solar [39]. In the pursuit of economic growth and development, Ethiopia has focalized on renewable energy production, vehemently engaged in the development of its renewable energy potential. Renewable energy resources include wind power, solar, geothermal, and biofuels are among the renewable energy sources practiced in Ethiopia.

\subsection{Hydropower}

Ethiopia is well-thought-out to be the Water Tower of Africa following the Democratic Republic of Congo with huge hydropower potential estimated up to 45,000 MW. The mountainous landscape in most parts of the country makes many of the nation's water resources suitable for hydro-electricity generation ranging from small to grand hydropower plants [40]. Ethiopia has 11 major river basins, of which eight are recognized for hydroelectric power generation potential with a predicted capacity of 159,300 GWh/year. Around 300 hydropower plants can be installed in eight basins, of which 102 are large scale (>60 MW) and 198 are small scale ( $<40 \mathrm{MW})$ [30].The paramount share of the total installed electric power capacity of Ethiopia is generated from hydropower plants which are accounted for $92 \%$ of the total generated capacity [22]. In order to secure its surplus 
energy demand, Ethiopia has engaged itself in unprecedented multibillion-dollar energy projects. These projects are mostly renewable energy including a number of hydropower plant projects, like $>5$ GW GERD on the Blue Nile river and 254 MW GenaleDawa Dam on Genale river. Currently, Ethiopia has constructed 17 on-grid hydropower plants, out of which 14 are Inter Connected System (ICS) and 3 are Self-contained System (SCS), with a total installed capacity of $4067.759 \mathrm{MW}$ as shown in Table 2.

Table 2. Hydropower plants and total on-grid installed capacity [22].

\begin{tabular}{|c|c|c|c|c|}
\hline & No & Hydropower Plants & Installed Capacity (MW) & Year of Commissioning \\
\hline \multirow{14}{*}{ 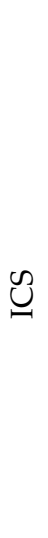 } & 1 & Koka HPP & 43.2 & 1960 \\
\hline & 2 & Tis Abbai I HPP & 11.4 & 1964 \\
\hline & 3 & Awash II HPP & 32 & 1966 \\
\hline & 4 & Fincha HPP & 134 & 1973 \\
\hline & 5 & Awash III HPP & 32 & 1974 \\
\hline & 6 & MelkaWakena & 153 & 1988 \\
\hline & 7 & Tis Abbai II HPP & 73 & 2001 \\
\hline & 8 & Gilgel Gibe I & 184 & 2004 \\
\hline & 9 & Tekeze & 300 & 2009 \\
\hline & 10 & Gilgel Gibe II & 420 & 2010 \\
\hline & 11 & Tana Beles & 460 & 2010 \\
\hline & 12 & Fincha-Amerti Neshe & 95 & 2011 \\
\hline & 13 & Gilgel Gibe III & 1870 & 2016 \\
\hline & 14 & Genale Dawa III & 254 & 2020 \\
\hline \multirow{6}{*}{$\bigcup_{\infty}^{n}$} & & Hydro & 4061.6 & \\
\hline & 1 & Yadot Hydro & 0.35 & \\
\hline & 2 & Sor Hydro & 5.00 & \\
\hline & 3 & Dembi Hydro & 0.80 & \\
\hline & & Hydro & 6.15 & \\
\hline & & Total & 4067.759 & \\
\hline
\end{tabular}

The small hydropower self-contained system (SCS), which consists of three small hydropower plants, operates in remote areas owned by private institutions. The contribution from the small hydropower plants is about $6 \mathrm{MW}$ despite the availability of many small rivers and waterfalls that could be used for electricity generation to supply more off-grids in rural areas of Ethiopia. Small hydropower plants often stay realistic only in the regions with no access to the national grid, since the total cost of SCS electricity is higher compared to ICS power plants. The share of electricity generated from hydropower will be the dominant source of electricity in Ethiopia for the next ten years [41].

\subsection{Biomass Resources}

Biomass is considered to be a backbone of energy sources in developing countries, especially in sub-Saharan African countries like Ethiopia [42]. Biomass is a natural resource used all over the world for versatile purposes, mainly used for lighting and cooking. Biomass resources encompass woody biomass (cellulose, hemicelluloses, lignin, lipids, proteins and simple sugars), crop residue, animal waste, dung, sewage, agricultural, and municipal wastes. In Ethiopia, the biomass energy resources are wood, agricultural residue, municipal and industrial wastes and animal wastes. The total energy that can be consumed annually from bio-energy resources is estimated to be about 153.4 million tones. Out of this, the share of the woody biomass is estimated to be $73 \%$ (wood $69 \%$ and charcoal $4 \%)$, followed by animal dung (14\%) and residue (13\%), see Figure 8 [43,44]. Most of the rural society depends on freely collected woody biomass, crop residue, and animal dung. However, the utilization is still being unbalanced, consumption is higher than re-plantation. 


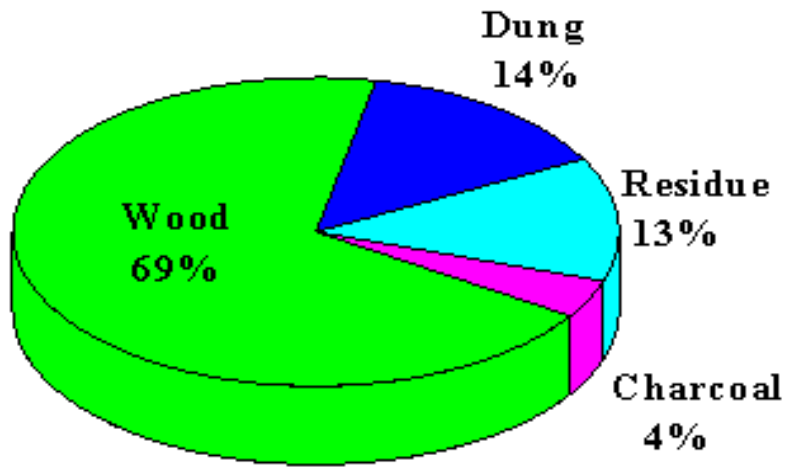

Figure 8. The share of different biomass resources as fuel in Ethiopia, 2013 [44].

\subsubsection{Firewood}

Firewood resources grow within and outside forests. It is the most dominant source of energy in Ethiopia and is exploited significantly in rural and urban areas for cooking and many different heating applications [45]. Sustainably sourced firewood enables carbon sequestration. Replacing fossil fuel with sustainably produced firewood decreases $2-3 \mathrm{~kg}$ of $\mathrm{CO}_{2}$ for each $\mathrm{kg}$ of fossil fuel, indicating using sustainably sourced firewood as a source of energy is carbon-neutral [46]. Woody biomass fuel is the largest form of primary energy consumed in Ethiopia. More than $90 \%$ of the domestic supplies of industrial wood and firewood comes from the natural forests which are the main sources of wood products [47]. Fuel wood accounts for the bulk of the wood used and is the predominant preferred domestic fuel in both rural and urban areas of Ethiopia. In 2016/17, the average annual firewood production (in both commercial and non-commercial firewood) was estimated to be about 1.2 Tera Joule [47]. The firewood consumption was nearly the same. The wood fuel energy supply and demand imbalance are exerting considerable pressure on the remaining forest and vegetation stocks, in so doing accelerating the processes of land degradation and deforestation, which is the largest source of GHG emissions in the country [48]. On the other hand, charcoal is an important fuel particularly for urban dwellers [49]. The averages annual charcoal consumption is estimated to be 230,000 tonnes, of which, $70 \%$ of charcoal is used in towns [50]. Despite the use of firewood causes deforestation, the demand for charcoal has grown faster because of the increase in urbanization, and increasing economic efficiency scores up to $80 \%$ [50]. In order to make wood fuel sustainable energy sources, Ethiopia can take examples of the European scenario. A study conducted in Greece suggested to increasing the production of certain types of woods that have high heating values (woods that have high heat capacity) [51,52]. The Ethiopian government has started a tree planting campaign aimed at curbing climate change and deforestation through "Green legacy initiatives" which was started in 2018 by the Prime minster. However, we recommend cultivating a certain type of trees that have a high energy density.

\subsubsection{Residues and Dung}

The rural household predominantly make use of agricultural residues for cooking and baking, using very low-efficiency cooking stoves. Coffee husk, cotton stalk, sesame husk and khat stem are some of the commercially available agricultural residues in the country. The total consumption of residues in rural and urban areas is 19.3 million tons per year and 0.4 million tons per year, respectively. Animal dung in the form of dung cake is one of the most common traditional biomasses used by households for cooking. Animal dung is also used for the production of biogas. In some rural parts of the country biogas production from animal dung is started at the household level. According to CSA (2009/10) survey, the country's livestock population is about 150 million [53]. It is seen that about 42 million tonnes of dry weight dung is produced annually from the total livestock. Cattle (cows and oxen) account for the highest share of dung production which is about $84 \%$ annually [53]. The total consumption of dung in rural and urban areas is 20.7 million tonnes 
per year and 2.1 million tons per year, respectively. Decentralized energy projects that involve converting animal waste to biogas are also in progress. The country has already installed more than 860 biogas digesters [6,54]. It has a huge potential in animal waste and cow dung, and the benefits of biogas technology are high of important and therefore, installing biogas technologies in the rural households can pave the way for sustainable energy production and consumption without connected to the national grid.

\subsubsection{Municipal Solid Waste}

Solid waste management is a serious challenge facing in almost all cities/towns, particularly in developing countries including Ethiopia. Moreover, wastes cause air pollution, GHG emissions, health problems, and so on [55,56]. However, wastes can also be wealth if properly managed and utilized. Municipal solid waste can be used to produce methane gas, which is then used to generate electricity. The technology for the conversion of waste into electricity is well matured and has been used in different parts of the world. It is also one of the potential bioenergy resources of Ethiopia accumulated in cities and towns in the form of landfills $[55,56]$. The amount of municipal solid waste depends on the population of the cities. Most cities and towns of the country including the capital Addis Ababa, are highly populated. The total solid waste generation in rural and urban areas of Ethiopia is estimated from 0.6 to 1.8 and 2.2-7 million tons/year, respectively [55]. For instance, the daily average municipal solid waste generation rate in Addis Ababa is $0.45 \mathrm{~kg}$ per capita per day [57]. Therefore, the total daily and annual municipal solid waste generation of Addis Ababa would be about 2970 and 1,084,050 tons, respectively in 2017. Unfortunately, only about $65 \%$ of the waste produced per day is collected and disposed off in a proper landfills, $5 \%$ is recycled, $5 \%$ is composted and the rest is uncollected and dumped illegally [57]. Very recently, a new Reppie waste-to-energy plant has been established to generate around $25 \mathrm{MW}$ of electricity from the waste. The plant is said to be African's first waste to energy facility, which was inaugurated in 2018, and currently, it incinerates solid waste of 1000 tons every day, which is roughly $80 \%$ of the city's garbage. The project was constructed at a cost of US\$95 million [31,58].

\subsubsection{Bioethanol Production in Ethiopia}

In Ethiopia, biofuel production has been used as a source of energy in the transport and household sectors. Mostly, bioethanol produced from sugar factories has been used in the transport sector. Bioethanol blends for use in transportation and power generation [49]. Currently, there are three bioethanol blending stations in Ethiopia, Nile Petroleum, Oil Libya, and National Oil Company [53].

Bioethanol production from sugarcane is less expensive since the fermentation process could be made straight away. Ethiopia is gifted with suitable land, climate, and enormous water supplies for sugarcane cultivation. The identified land suitable for sugarcane plantation is approximately 700,000 hectares and currently, nearly half a million hectares of land is allocated for sugarcane farming [53]. Bioethanol is produced from molasses, the byproduct of sugar. From 1 ton of crushed cane, about 3-4\% final molasses can be found; and 1 ton of molasses can produce about $250 \mathrm{~L}$ of bioethanol [53]. In 2014/15 about 20.5 million liters of bioethanol was supplied to the energy system of the country and entirely used in the transport sector [44]. The Ethiopian sugar corporation has planned to intensify the annual production of bioethanol to 28.1 million liters by the end of the second GDP from the existing factories and the others like; Tandaho and Wonji/Shewa expansion projects, and from recent sugar factories [25].

In addition to the production of sugar and bioethanol, most of the sugar factories produce energy from bagasse, the byproduct of sugar factories. The energy produced from bagasse is used for steam production and electricity generation for their own consumption and is connected to the national electricity grid [53]. Sugar factories such as Tendaho, Wonji/showa, Fincha and Metehara have a capacity to generate 60, 31, 31 and 9 MW of electric power, respectively. As can be seen in Figure 9, the Metehara sugar factory 
produces $9 \mathrm{MW}$ of electric power and is entirely used by the factory itself. However, Tendaho, Wonji/showa, Fincha have been contributing 38, 20 and $10 \mathrm{MW}$ of electric power, respectively to the national electricity grid [59].

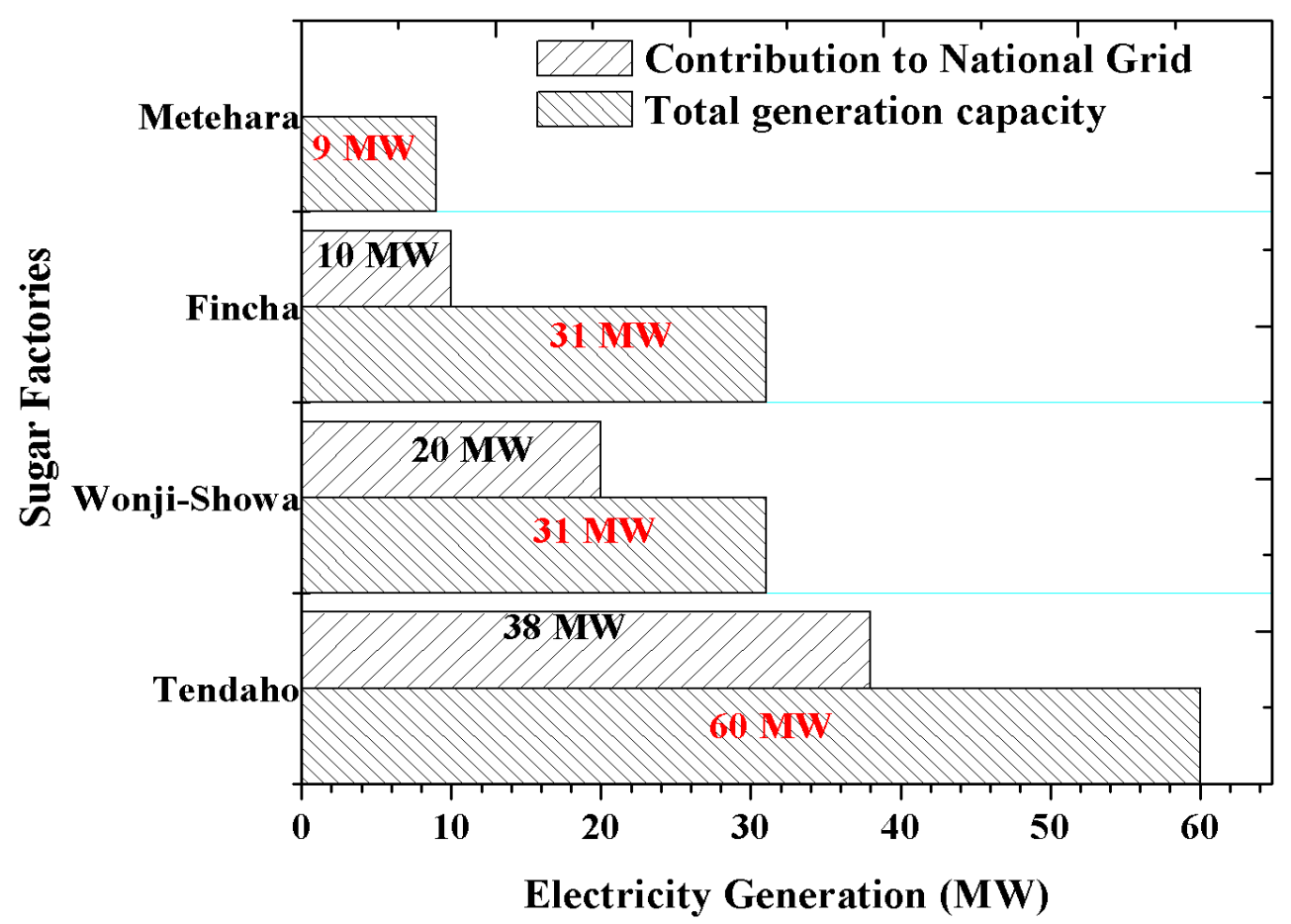

Figure 9. Bagasse energy generation capacity of sugar factories in Ethiopia and their contributions to the National grid [59].

\subsubsection{Biodiesel Production in Ethiopia}

Biodiesel is produced from different vegetable oil and animal fats via transesterification reaction in the presence of alcohol and catalyst. Oil such as Jatropha curcus, palm oil and castor bean oil are the most suitable and widely used ones. The country has substantial potential for biodiesel production up to a level of 5 to 10 million tons per annum [53].

\subsection{Wind Energy}

Ethiopia is a landlocked country and has no coastline which would be the main wind farm. However, the geographical location, the summer monsoon, tropical Easterlies, and local convergence over the Red Sea contribute a significant amount of windiness in the country. Moreover, Tana Lake, mountains, hills, plains and gaps in the mountains can have comparable good conditions and locations for wind energy $[60,61]$

As a result, Ethiopia has a huge amount of wind energy potential estimated to be 1,350,000 MW, areas which are moderately suitable for wind power are also included to the gross wind energy potential [1,9]. A previous study reported on the average monthly wind speed at six different locations. Addis Ababa (09"02' N, 38"42' E, $2408 \mathrm{~m})$; Mekele

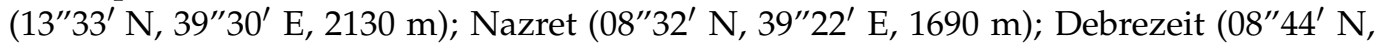
39"02' E $1850 \mathrm{~m})$, Debre Markos (10"20' N, 37"43' E) and Dejen district (24.03"13' N, $58^{\prime \prime} 07^{\prime}$ E $2396 \mathrm{~m}$ ) was reported as shown in Figure 10 [8,61]. The result shows that monthly average wind speed for Addis Ababa, Mekele, Nazareth and Debrezeit, Debre Markos and Dejen are 4.2, 3.8, 4, 2.5, 3.7 and $3.1 \mathrm{~m} / \mathrm{s}$, respectively. The wind speed in the summer season (June, July and August) is relatively lower in some cities (Addis Ababa, Mekele, Dejen district and Debrezeit) compared to wind speeds for Debre Markos and Nazareth in the same season (Figure 10a). The probability density function of wind for Dejen district is shown in Figure 10b, indicating that the average wind speed in Dejen District is around $3.1 \mathrm{~m} / \mathrm{s}$. 

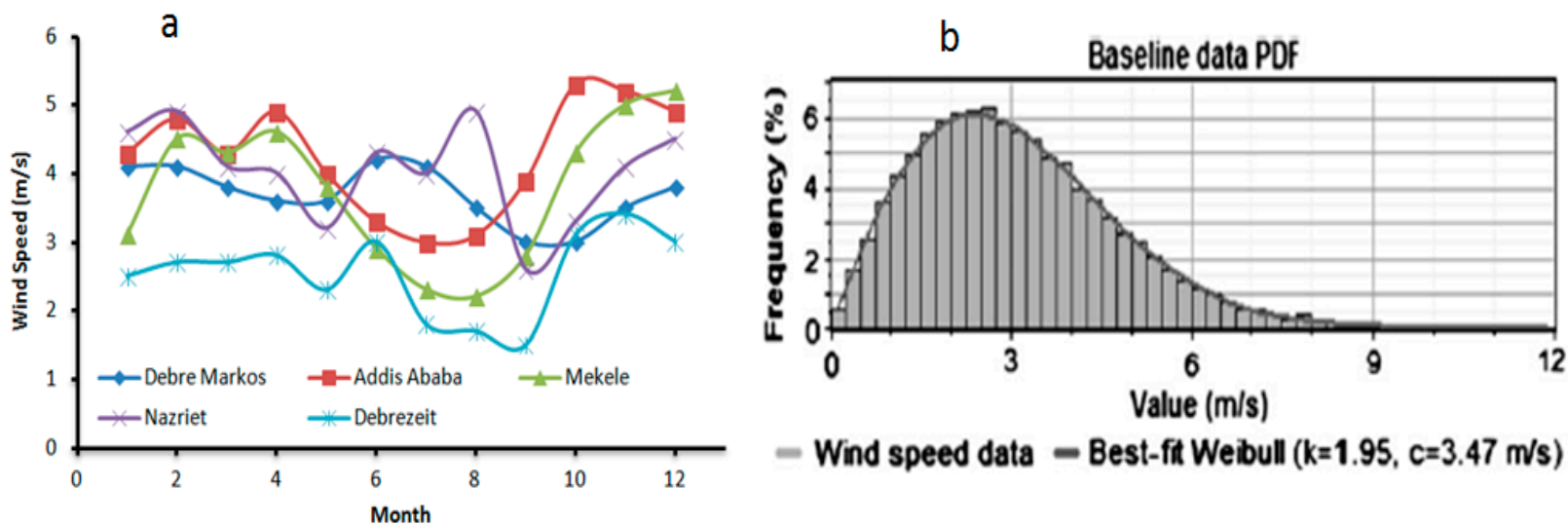

Figure 10. (a) Monthly average wind speeds at the five locations, (b) Probability density function of wind speed (at $10 \mathrm{~m}$ height) in Dejen District [61].

Currently, there are only three wind farm power plants (Adama I, Ashegoda and Adama II wind farms) operating with an installed capacity of $324 \mathrm{MW}$ in total. In addition to this, there are different wind farms in the country which are under construction and planning to be operational in the near future (Table 3).

Table 3. Installed wind farms and underdevelopment wind farms in Ethiopia.

\begin{tabular}{lcc}
\hline Name of Power Plants & Installed Capacity (MW) & In-Service Date Year \\
\hline Adama I & 51 & 2012 \\
Adama II & 153 & 2014 \\
Ashegonda & 120 & 2012 \\
Sub Total & 324 & \\
& Wind Farms under Development \\
Messebo & 42 & \\
Ayisha & 300 & \\
DebreBirhan wind park & 100 & \\
Asela & 100 & \\
Adama III & 150 & \\
Sub Total & 692 & \\
\hline
\end{tabular}

\subsection{Solar Energy}

Ethiopia has plentiful solar energy resources, with the annual average irradiance is estimated to be $5.2 \mathrm{kWh} / \mathrm{m}^{2} /$ day. The seasonal variations in the country result in the change of irradiance that ranges a minimum of $4.5 \mathrm{kWh} / \mathrm{m}^{2} /$ day in July to a maximum of $5.6 \mathrm{kWh} / \mathrm{m}^{2} /$ day in February and March. This variation of solar resource mostly reflected on the different regions of the country, where a solar resource in the Central and Western highlands of the country is relatively lower while the North-Western, Eastern and rift valley lowlands of the country receive higher annual average irradiance well above $6 \mathrm{kWh} / \mathrm{m}^{2} /$ day, which is relatively constant throughout the year $[9,62]$. For instance, the monthly average daily solar radiation in different four cities of Ethiopia is shown in Figure 11. It indicates that the lowest solar radiation ranged between 4 and $5.6 \mathrm{kWh} / \mathrm{m}^{2} /$ day in June to September, while the maximum average solar radiation is between 5.6 and $7 \mathrm{kWh} / \mathrm{m}^{2} /$ day from October to May season. This figure coincides with the average annual irradiation estimated around $2000 \mathrm{kWh} / \mathrm{m}^{2}$ in the tropical zone, of which Ethiopia is a part $[8,61]$. 


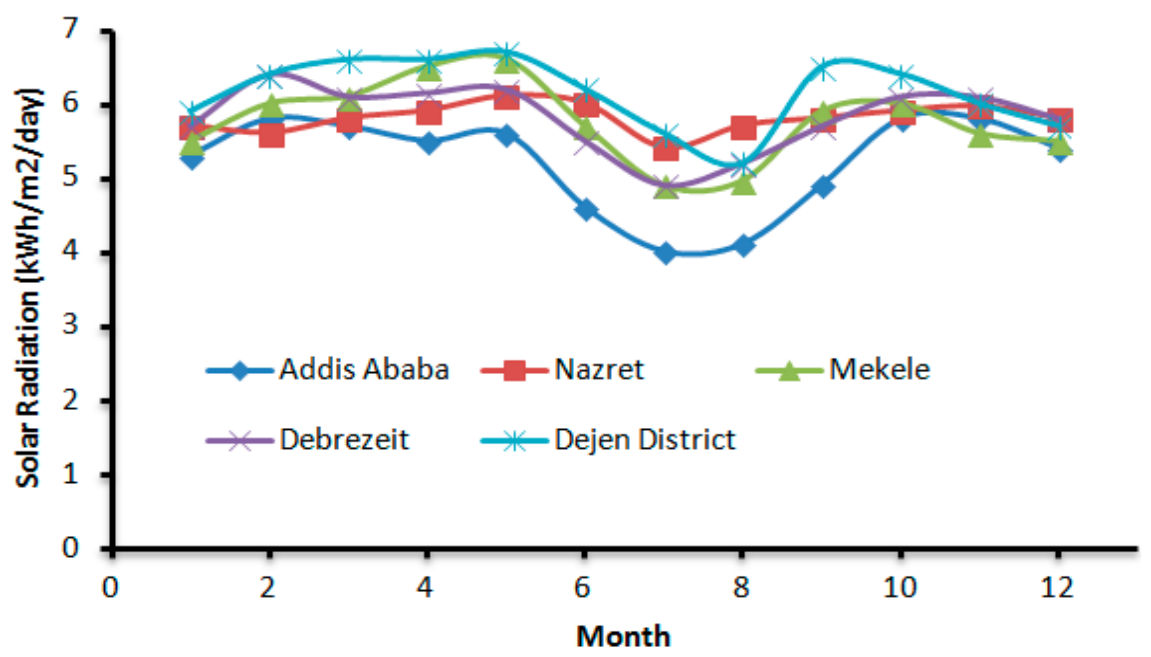

Figure 11. Monthly average daily solar radiation in different five cities of Ethiopia [61].

Despite this huge solar power resource, there is no national on-grid connected solar power plant built in the country except small-scale off-grid PV systems installed in the rural area in the mid-1980s. As shown in Figure 12a, off-grid telecom and off-grid residential applications account for $87 \%$ and $13 \%$ of the total installed PV capacity in Ethiopia.
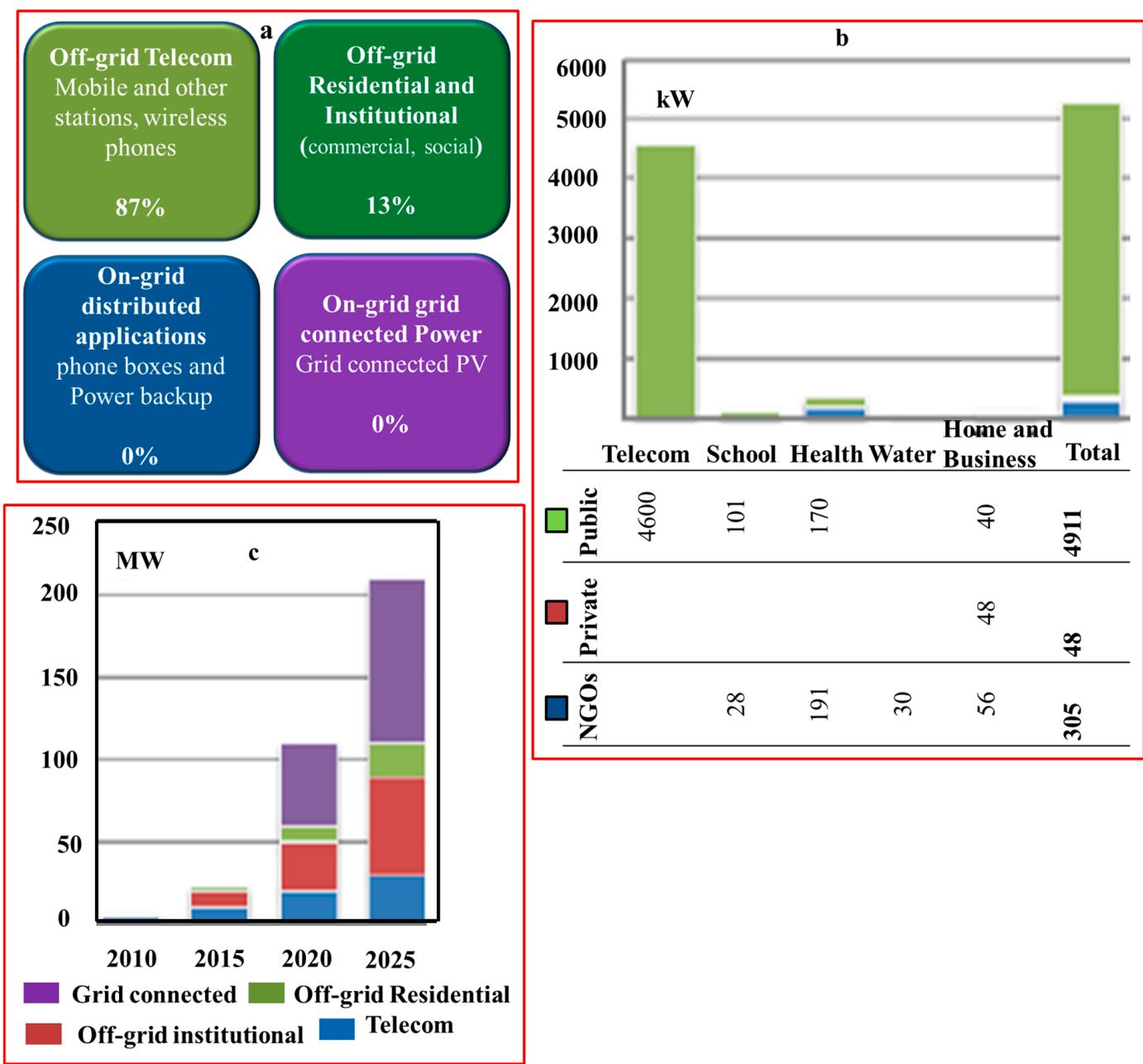

Figure 12. (a) Share of off-grid in small-scale solar PV systems for Telecom and residential applications, (b) PV systems installed and applications in Ethiopia, (c) solar PV demand in Ethiopia [11]. 


\subsubsection{PV System in Ethiopia}

In 1985, the first PV with $10.5 \mathrm{~kW}$ systems were installed for rural home and school lighting in Central Ethiopia which served 300 rural households through a micro-grid in the village. This system was later upgraded to $30 \mathrm{~kW}$ in 1989 to provide power for the village water pump and grain mill $[9,11,63]$. The solar energy from installed PV systems is mostly applicable for off-grid telecom systems (particularly for mobile and landline network stations), which account for $87 \%$ of total installations of PV systems in rural areas. In addition, installed PV systems are also used mostly for public sectors such as social institutions including health institutions, schools, water pumping, and for electrifications of some residential customers in rural areas. Figure $12 \mathrm{~b}$ shows that telecom application of $\mathrm{PV}$, particularly for mobile network supply, is increasing rapidly and this sector is expected to increase more due to the near universal access to the mobile network planned by the government. It should be noted that solar energy in Ethiopia contributes to the great increase in rural connectivity due to PV-powered mobile stations and PV-powered wireless phone stations, hence contributing to information access in the countryside.

\subsubsection{Demand for Solar PV in Ethiopia}

Short-term demand for the off-grid PV system applications will be dominant but, grid-connected PV may become important in the medium- and long-term plan. Short-term plans that have direct relevance for the PV sector include plans to produce and distribute 3,600,000 solar lanterns, 400,000 household solar PVs, 3600 institutional solar PVs, 500 solar thermals and 3600 solar cookers are also integral part of the targets. With these targets, the GoE is also aimed at universal electrification access of 35\% population in 2025 through an off-grid solar system [14]. In addition, the GoE has planned to increase mobile phone ownership to 103.6 million as planned in the growth and transformation plan II (GTP II) $[9,25]$, showing that there will be more energy demand from off-grid systems in the countryside.

Currently, there is a trend of growing interest towards small-scale solar PV systems market in the country, primarily addressing demands from health institutions, schools, religious institutions (i.e., churches and mosques) and community water supply systems. Not only off-grid PV systems, but also grid-connected PV is likely to be a major market in Ethiopia in the long-term [11].

Figure 12c shows that the demand for grid connected solar PV systems will increase to around $150 \mathrm{MW}$ by 2025 . The GoE has recently begun grid connected solar PV projects in the country. For instance, in May 2016, the state-owned Ethiopian power utility has a launched tender process of the USD 120 million projects to build 100 MW solar power in Metahara, $200 \mathrm{~km}$ east of Addis Ababa. This is a part of the government's plan to diversify its energy mix and increase the rate of electrification. Moreover, there are other two solar power projects each with a capacity of $125 \mathrm{MW}$ planned by the Ethiopian electric power (EEP) $[9,64]$. Even though such positive initiations are taken by the GoE, yet, PV equipment and accessories are not always available in the local commercial market in quantities and sizes the market requires. Other challenges regarding to solar PV systems in Ethiopia are associated with a lack of financial institutes to promote harnessing solar energy and lack of highly skilled technicians with technical capability to design, size, and install larger and more complex solar PV systems.

\subsection{Geothermal}

Ethiopia is one of the few countries in Africa with a significant potential of geothermal energy resources. Long-term geothermal energy exploration in Ethiopia is started in 1969. Recently, an inventory of the possible geothermal resource areas within the Ethiopian sector of the East African Rift valley system has been built up. Of the many inventory locations within the rift valley that are believed to have potential geothermal energy resources, more than 16 locations (Figure 13) are judged to have the potential for high enthalpy resource development, including for electricity generation $[17,65]$. 


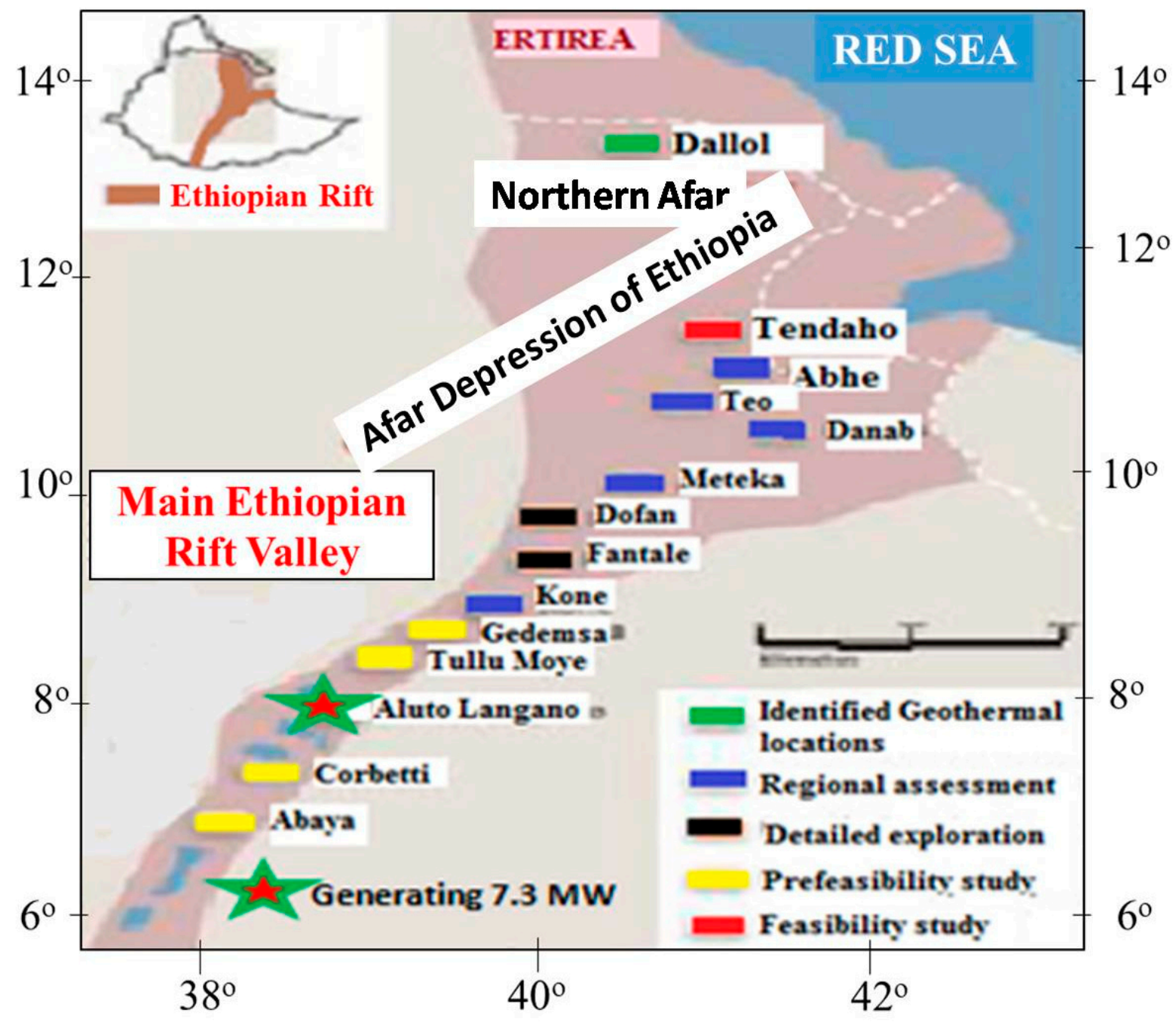

Figure 13. The locations of Geothermal energy resource in the rift valley of Ethiopia $[8,17]$.

Although huge numbers of geothermal resources are available in Ethiopia, most of it only used traditionally by local people mainly for hot springs or steam bathing. For instance, there is large-scale state operating recreational facilities like a swimming pool in Sodore, near the city of Nazareth; and hot spring bathing facilities ("fil wuha") are available in the capital Addis Ababa. In addition, there is a state operating sanitarium facility, and there are local steam bathing locations in Boku near Nazareth city.

Geothermal technologies make up a small fraction of Ethiopia's power supply, but can be attractive options for adequate resources exist. A recent study showed that the potential of geothermal energy in Ethiopia is about 10,000 MW [66].

The Aluto-Langano, one of the 16 spotted geothermal potentials, is the only geothermal power generating plant, which was installed in 1999 in Ethiopia. Currently, it has a generating capacity of 7.3 MW $[9,47,66]$. Recently the GoE has announced the developmental plan of six projects to be completed in the near future with a total an installed capacity of $450 \mathrm{MW}$ (Table 4). As shown in Table 4 the GoE has planned the increment of geothermal energy contribution to the current energy consumption of the country, which is mainly based on hydropower energy. As part of increasing energy generation from geothermal, the GoE has recently signed an agreement with two companies to generate $1000 \mathrm{MW}$ from two sites (Corbetti and Tulu Moye) [66]. 
Table 4. Geothermal power plants planned to commission power at the planned year [17].

\begin{tabular}{ccc}
\hline Name of Power Plants & Installed Capacity (MW) & Planned Year of Commissioning \\
\hline Aluto-Langano & 75 & 2020 \\
Tendaho & 100 & 2020 \\
Corbetti & 75 & 2020 \\
Abaya & 100 & 2020 \\
Tulu Moye & 40 & 2020 \\
Dofan Project & 60 & 2020 \\
Total & 450 & \\
\hline
\end{tabular}

The activities by the Ethiopian Institute of Geological Survey (EIGS) related to geothermal energy are (i) monitoring (geochemical and reservoir engineering) of the potential geothermal fields; (ii) Detailed geological mapping and geophysical studies of the Lakes District area (e.g., Tulu Moye, Gedemsa, Abaya); (iii) sampling of water samples, for isotope, chemical and gas analysis from surface geothermal manifestations around main Ethiopian rift, Southern Afar and Northern Afar regions.

\section{Prospective Blue Energy Sources and Technologies}

Salinity Gradient Energy or Salinity Gradient Power (SGP) also known as "Blue Energy" is the energy extracted by mixing two aqueous salt solutions of different salinity. It is completely clean (green), renewable and sustainable with no $\mathrm{CO}_{2}$ emissions or other toxic gas that may affect the global climate. Considering all statuaries, the global potential of salinity gradient energy reaches up to $1.2 \mathrm{TW}$. The global technical potential is estimated to be around $647 \mathrm{GW}$ equivalent to about 5177 terawatt-hours (TWh) reaching $23 \%$ of global electricity consumption in 2011 [67].

Although a landlocked country, Ethiopia is endowed with a huge number of freshwater resources. The country is divided into twelve basins out of which eight are river basins, one is a lake basin with the remaining dry basins. The most representative potential salt resources are located in the northern part of the country: the hyper saline Lake Afrera and Karumin the geological depression termed "Denakil Depression" can be the potential sources of saltwater. Lake Afrera is extremely salty and is still mined. Lake Karum is also another hypersaline lake surrounded by a salt pan and still mined for salt. For instance, up to $16,800 \mathrm{~kJ}$ SGP can be generated by mixing such saltwater resources of up to $5 \mathrm{M} \mathrm{NaCl}$ with river water $(\sim 0.017 \mathrm{M})$ from such a resource $(5 \mathrm{M})$. The other potential saline resources could be from industries, e.g., from paint industries that are associated with high content of aqueous sulfate effluents. SGP can also be coupled with potential Reverse Osmosis systems that operate on saline waters like Lake Beseka located $100 \mathrm{~km}$ from Addis Ababa in the south. Identification of the potential water and wastewater resources and the associated SGP is an open area for investigation.

There are different technologies for harnessing SGP [68-72] with two of the membranebased processes, Reverse Electrodialysis (RED) and Pressure Retarded Osmosis (PRO), representing the most promising technologies.

In our recent perspective article, we have presented the key membrane-based energy technologies for potential implementation in Ethiopia [13]. Salinity gradient energy and hydrogen technologies can be considered among the most promising technologies for the prospective R\&D topics in the area of renewable energy.

In RED, cation exchange membranes (CEMs) and anion exchange membranes (AEMs) are assembled in an alternative way to create two types of flow compartments (Figure 14); namely high concentration compartments (HCCs) and low concentration compartment (LCCs). When these compartments are fed with respective HCC and LCC solutions, a salinity gradient is created that drives the selective transport of ions through the ion exchange membranes towards electrodes. Electrical energy is generated by redox reactions occurring over electrodes [70,73]. 


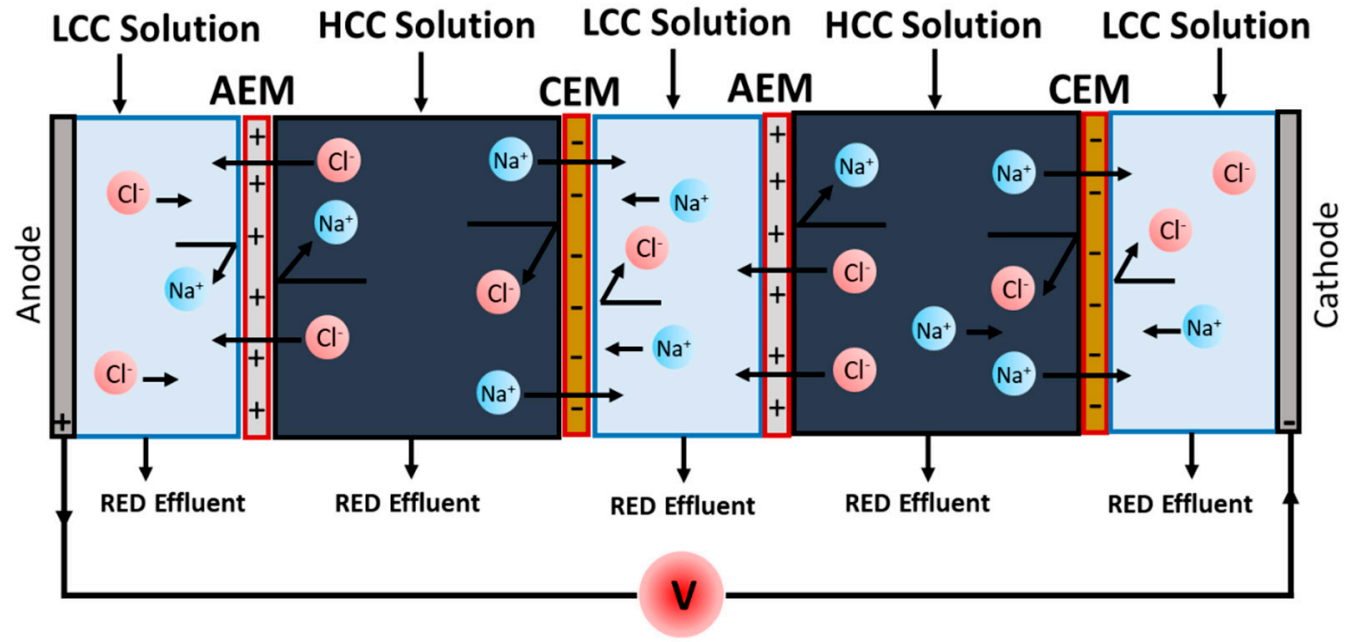

Figure 14. Schematic illustration of RED stack [70].

PRO uses semi-permeable membrane through which low concentration solutions diffuse into high concentration solution [70]. With the net driving force across the membrane being the osmotic pressure that stretches the volume high concentration solutions driving a turbine to produce electricity [70]. The pressure exchanger receives part of the pressurized high concentration solution to transfer the pressure of the draw solution to the feed solution thereby reducing the cost of the technology.

The main challenges in PRO are the fouling of the membrane and finding a suitable membrane and pressure exchanger system, required for low energy consumption. With the advance of these different membrane technologies, and the prospective development of membranes for energy applications, RED and PRO represent prospective alternative clean energy technologies for potential implementation in Ethiopia along with other renewable energy resources.

Hydrogen is a clean and versatile future energy source long considered as an alternative energy vector to fossil fuels for powering industrial and transport sectors as well as for household purposes including heating. It is widely applied in industries for ammonia synthesis, fertilizers, metallurgical reduction, for steel refining and crude oil processing, etc. Hydrogen can be produced by different methods including thermal, electrolytic, and photolytic pathways from various sources like hydrocarbons, water or biomass. The most common method for hydrogen production is steam reforming of methane or other hydrocarbons, which is associated with a huge $\mathrm{CO}_{2}$ emission. Alternatively, water electrolysis represents a well-established mature technology for hydrogen production. Biomass gasification is another mature technology for the production of green hydrogen at a controlled process involving heat, steam, and oxygen. Ethiopia displays a huge amount of water and biomass resources that can be used for hydrogen production through suitable technological pathways. In this regard, low-temperature membrane processes and high-temperature systems for water electrolyzer [74], as well as biomass gasification through thermo-chemical and bio-chemical/biological methods $[75,76]$ present a potentially deployable methods for hydrogen production.

\section{Challenges of Renewable Energy Production in Ethiopia}

Lack of access to modern electricity means a lack of opportunities for social services such as water supply, health services and educational facilities for which modern energy sources are essential input. There are several challenges that mired the harnessing and developments of renewable energies in Ethiopia. Generally, the main challenges of harnessing renewable energy sources in Ethiopia can be categorized as follows [30,60,77]:

i. Technical and human capacity barriers: There is a lack of developed and adapted energy technologies that could fit specific local conditions in the country. One 
reason that could cause lack of locally developed energy technologies is due to limited on-job training experiences. These may, in turn, are due to a shortage of enough funding for the development of energy sectors, law level of socio-economic, a lack of technical (skilled manpower) for the maintenance of energy generation technologies, and institutional incompetence in terms of the energy sectors.

ii. Economic and financial barriers: There is limited finance for the development of renewable energy sources due to the relatively high cost of geothermal and wind energy technologies.

iii. Underdeveloped rural energy infrastructures and markets: The low level of rural energy infrastructures and energy markets resulted in low participation of private energy sectors as the startup capital is intensified. One reason for this is that there is less experience in commercial operations and weak delivery systems in the country.

iv. Information barriers: There is a lack of detailed and updated energy data as well as maps for the development of renewable energy technologies in Ethiopia.

v. Political barriers: The adverse impacts of political conflicts in the Eastern Africa region as well as internal conflicts hindered the development of renewable energy sources. For example, the Grand Ethiopian Renaissance Dam (GERD) hydropower development has been recently politicized in the East Africa region, which significantly contributes to the slowdown of renewable energy development.

Specific challenges for different renewable energy sources are explained below:

A. Hydropower

The key challenges that hinder the exploitations and developments of hydropower are as follows [30,60,77]:

Lack of skilled manpower, up-to-date technologies and internally raised funds. The scattered settlements of the population in the rural and remote areas make it difficult to develop grid electricity and supply expenses. In addition, the electricity consumption is very low in these areas, that makes the return investment less attractive.

○ The persistent political instability in the Horn of Africa has influence and stalled cross-border electricity trade.

0 The participation of the private sector is limited. This can be attributed to the lack of updated information, awareness and motivation.

- Institutional weakness and lack of conducive environment and a working policy from the government side.

Some donors and financers are reluctant to support politically sensitive hydropower projects.

B. Biomass resources

The following challenges are identified as the main factors that adversely affect the exploitation and development of biomass resources in Ethiopia [60,78].

Lack of coherent and clear policies: the country has no well-thought comprehensible policy that guides activities in the biomass energy sectors and helps to harness the energy from the biomass sector.

- The biomass resources in Ethiopia are unsustainable: i.e., the rate of biomass extraction exceeds that of planting. This results in environmental degradation. Wasteful utilization of biomass energy: Biomass energy utilization at the household level is characterized by insufficient. For instance, the use of firewood and charcoal as a means of cooking especially in the rural areas due to the high price of kerosene unintentionally put pressure on biomass use.

- Absences of institutional capacity: There is no capable institutions with clear directives that focused on long term program dedicated to biomass.

Inefficient energy consumption: biomass energy use is wasteful in the rural areas of the country as traditional cooking stoves are being used. 
The free-good nature of biomass in Ethiopia: In rural areas of the country, biomass is a "free-good" that can be found with no cost. This does not incentivize consumers to conserve biomass energy.

Shortage of storage center, properly designed solid waste collection route systems and time schedule, and facilities to manage urban wastes.

Lack of operation equipment and illegal and poor condition of the final dumpsite.

Moreover, lack of sufficient funds to construct waste to energy facilities.

Lack of promotion on-waste reduction such as waste separation, recycling and composting.

C. Wind energy

The following factors can be taken as challenges in harnessing wind energy in Ethiopia $[60,79]$.

Despite Ethiopia beinga landlocked country with no offshore places which can be the main wind energy source, there is still a potential forwind energy in the highlands of Ethiopia. However, there is a lack of investment capital for wind energy technology development.

- Lack of high-level technical skills and the cost of wind turbine technology is high. There is also little awareness and motivation on the potential for wind power.

Lack of basic transportation infrastructure makes it difficult to logistically transport wind turbines.

Lack of well organized research and capacity development.

Lack of good perceptions of the contribution of wind energy capacity.

D. Solar energy

The challenges in solar energy production in Ethiopia are as follows [14,60,79].

Insufficient technical skill: lack of skilled manpower (lack of maintenance and training facilities). Sustaining solar PV systems is directly connected to the long-term maintenance, repair, and replacement of batteries after they reach a regular lifespan. This is a great concern since maintaining solar PV systems requires highly technical skill manpower.

- Lack of innovative financing mechanism to compensate the cost of the system. This results in purchasing quality solar PV products remain a bottleneck, especially in the rural areas.

- There is no clear and coherent policy as well as the institutional capacity to ease the commercialization of the technology.

Consumers and policymakers do not have adequate awareness about the technology.

- The association between national dealers and local retailers and technician is poor, hence importing poor quality of products.

Undeveloped solar PV supply chains.

Lack of well organized research and capacity development.

Lack of adequate logistics and transportation systems for the local solar technologies development and manufacturing.

E. Geothermal energy

The most important barriers in harnessing and developing geothermal energy in Ethiopia are [47,66]:

Lack of scientific and technical knowledge for developing the system.

Lack of funding and financing for the system.

Lack of coherent policy and framework.

Inadequacy of funding for the feasibility study.

Lack of moderateley high tariffs for geothermal energy to cover the costs and finance new investment. 


\section{Conclusions}

Despite persistent challenges, Ethiopia is undertaking great effort towards the development of renewable energy technologies including the development of hydropower, wind, solar and geothermal energy. The country has untapped renewable energy resources, in which so far, the country has exploited only $5 \%$ of its full hydropower potential, and other sources are not fully developed. Hence, over 65 million people still do not have access to electricity. Currently, Ethiopia is heavily reliant on biomass-based energy for household purposes. The country is hoping to complete the Grand Ethiopian renaissance dam in the coming few years which will be utilized mainly for electricity generation. The first filling of the dam (4.9 billion cubic meters of water) has completed in July 2020 and the second phase of filling of the dam in July 2021, indicating significant development of hydropower energy sources. Moreover, the country is also committed in the development of other renewable energy sources such as wind, solar and geothermal in different parts of the country mostly for rural electrification depending on geographical conditions. The potential drivers to promote renewable energy sources in Ethiopia are the multi-level process to improve implementation of renewable energy technologies. Thus, deploying renewable energy technologies in Ethiopia is strongly enabled and driven by the country's evolutionary economic growth, paradigm shift towards renewable energy source due to global climate change, rapid growth of energy demand, lower rate of electrification in rural areas, heavily subsidization from the GoE, rapid development of renewable technologies, grid integration and availability of ample renewable energy sources in the country. However, in addition to lack of skilled manpower and financial incentives, strong supportive policy shortcomings towards each renewable energy source and technologies and lack of adequate logistics and transportation for the local renewable technology development and manufacturing will likely hamper the deployment of renewable technologies in Ethiopia in short period of time. To overcome the pressing technical challenges for harnessing renewable energy resources in Ethiopia, promoting research and development with financial incentive will pave the way for sustainable environment and energy generation. Ethiopia has national energy policy directions for the development of renewable energy resources like solar energy for heat and power generation and wind energy for water pumping and irrigation. However, it is still incapable and insufficient considering economic and technological changes that happened around the globe in general, and in Ethiopia specifically, since the policy was launched. Therefore, the current new strategic plan should focus on energy sectors to support potential local energy technologies manufacturing industries, financial incentives on research, innovation and development: crucial steps that require immediate action by policymakers.

It is evident that Ethiopia has a huge amount of renewable energy sources that can achieve its energy demand and contribute to its economic growth in the future. To harness its renewable energy potentials, some renewable energy sources like hydropower and wind energies require the consumers to live in specific locations compared to solar energy. Therefore, solar energy provides more freedom to install small scale off-grid solar systems and is expected to expand in the rural areas of Ethiopia. This expansion of solar energy will also be more enabled by the decreasing cost of solar PV not only in Ethiopia, but also in East Africa countries.

Author Contributions: Conceptualization, G.A.T., A.T.B., R.A.T., Y.S.M., N.E.B. and G.A.G.; writing original draft preparation, G.A.T., A.T.B., R.A.T., Y.S.M., N.E.B. and G.A.G.; writing review and editing, G.A.T., A.T.B. and R.A.T. All authors have read and agreed to the published version of the manuscript.

Funding: G.A.T. acknowledges for the small funding provided by Addis Ababa University under thematic project (Grant No_. TR/036/2020 and RD/LT-095/2019).

Acknowledgments: All authors are grateful to the work facilities provided by Addis Ababa University (Ethiopia), Jigjiga University (Ethiopia) and Technical University of Denmark (Denmark). 
Conflicts of Interest: The authors declare no conflict of interest.

$\begin{array}{ll}\text { Abbreviations } \\ \text { AEM } & \text { anion exchange membrane } \\ \text { CEM } & \text { Cation exchange membrane } \\ \text { CIL } & \text { Cambridge Industries Limited } \\ \text { GHG } & \text { Greenhouse gases } \\ \text { GERD } & \text { Great Ethiopian Renaissance Dam } \\ \text { GoE } & \text { Government of Ethiopia } \\ \text { GTP-I } & \text { Growth and transformation plan I } \\ \text { GTP-II } & \text { Growth and transformation plan II } \\ \text { ICS } & \text { Inter connected system } \\ \text { PV } & \text { Photo voltaic } \\ \text { PRO } & \text { Pressure retarded osmosis } \\ \text { SCS } & \text { Self-contained system } \\ \text { SGP } & \text { Salinity gradient power }\end{array}$

\section{References}

1. Adams, S.; Klobodu, E.K.M.; Apio, A. Renewable and non-renewable energy, regime type and economic growth. Renew. Energy 2018, 125, 755-767. [CrossRef]

2. BP Energy Outlook 2018 Edition. 2018. 12-15, 24-29, 34, 46-48, 120-121. Available online: https://www.bp.com/content/dam/ bp/business-sites/en/global/corporate/pdfs/energy-economics/energy-outlook/bp-energy-outlook-2018.pdf (accessed on 13 September 2021). [CrossRef]

3. Dehghani-Sanij, A.R.; Bahadori, M. Ice-Houses: Energy, Architecture, and Sustainability; Elsevier, Imprint by Academic Press: Amsterdam, The Netherlands, 2021.

4. International Energy Agency. World Energy Outlook Special Report: Energy Access Outlook 2017 from Poverty to Prosperity. Available online: https://www.oecd.org/publications/energy-access-outlook-2017-9789264285569-en.htm (accessed on 19 May 2021).

5. Njoh, A.J. A systematic review of environmental determinants of renewable energy performance in Ethiopia: A PESTECH analysis. Renew. Sustain. Energy Rev. 2021, 147, 111243. [CrossRef]

6. Berhanu, M.; Jabasingh, S.A.; Kifile, Z. Expanding sustenance in Ethiopia based on renewable energy resources-A comprehensive review. Renew. Sustain. Energy Rev. 2017, 75, 1035-1045. [CrossRef]

7. Asress, M.B.; Simonovic, A.; Komarov, D.; Stupar, S. Wind energy resource development in Ethiopia as an alternative energy future beyond the dominant hydropower. Renew. Sustain. Energy Rev. 2013, 23, 366-378. [CrossRef]

8. EEPCo. Ethiopian Power Sector Development, Powering Africa. Available online: https://pubs.naruc.org/pub.cfm?id=537C1 4D4-2354-D714-511E-CB19B0D7EBD9 (accessed on 14 September 2021).

9. Mengistu, M.G.; Simane, B.; Eshete, G.; Workneh, T.S. A review on biogas technology and its contributions to sustainable rural livelihood in Ethiopia. Renew. Sustain. Energy Rev. 2015, 48, 306-316. [CrossRef]

10. Ethio-ResourceGroup. Solar Energy Vision for Ethiopia: Opportunities for Creating a Photovoltaic Industry in Ethiopia. Available online: https:/ / www.sun-connect-news.org/fileadmin/DATEIEN/PV-Industry-ET-04-09-12_final.pdf (accessed on 15 September 2021).

11. Getie, E.M. Poverty of Energy and Its Impact on Living Standards in Ethiopia. J. Electr. Comput. Eng. 2020, 2020. [CrossRef]

12. Besha, A.T.; Tsehaye, M.T.; Tiruye, G.A.; Gebreyohannes, A.Y.; Awoke, A.; Tufa, R.A. Deployable Membrane-Based Energy Technologies: The Ethiopian Prospect. Sustainability 2020, 12, 8792. [CrossRef]

13. Mugisha, J.; Ratemo, M.A.; BunaniKeza, B.C.; Kahveci, H. Assessing the opportunities and challenges facing the development of off-grid solar systems in Eastern Africa: The cases of Kenya, Ethiopia, and Rwanda. Energy Policy 2021, 150, 112131. [CrossRef]

14. International Energy Agency. Key World Energy Statistics. 2014. Available online: https://www.oecd-ilibrary.org/energy/keyworld-energy-statistics-2014_key_energ_stat-2014-en (accessed on 20 October 2020).

15. The World Bank; International Energy Agency. Program, the E.S.M.A. Sustainable Energy for All (SE4ALL) Database from the SE4ALL Global Tracking Framework. Available online: https:/ / data.worldbank.org/indicator / EG.ELC.ACCS.ZS?end=2019 \&locations=ET\&start=2000 (accessed on 15 September 2021).

16. MoWE. Scaling-Up Renewable Energy Program Ethiopia Investment Plan. Available online: https://www.oecd.org/env/cc/ TADELE_FDREEthiopiaScaling-UpRenewableEnergyProgram2012.pdf (accessed on 15 September 2021).

17. IEA; IRENA; UNSD; World Bank; WHO. Tracking SDG 7: The Energy Progress Report. 2021. Available online: https:// trackingsdg7.esmap.org/data/files/download-documents/2021_tracking_sdg7_report.pdf (accessed on 15 September 2021).

18. IEA. Africa Energy Outlook 2019, Overview: Ethiopia. Available online: www.iea.org/reports/africa-energy-outlook-2019 (accessed on 20 June 2021). 
19. MoWIE-Ethiopia. Energy Balance and Statistics for Years 2010/11-2016/17. Available online: http:/ /www.mowie.gov.et/web/ guest/home (accessed on 20 August 2020).

20. Negash, M.; Riera, O. Biodiesel value chain and access to energy in Ethiopia: Policies and business prospects. Renew. Sustain. Energy Rev. 2014, 39, 975-985. [CrossRef]

21. Mondal, M.A.H.; Bryan, E.; Ringler, C.; Mekonnen, D.; Rosegrant, M. Ethiopian energy status and demand scenarios: Prospects to improve energy efficiency and mitigate GHG emissions. Energy 2018, 149, 161-172. [CrossRef]

22. Khan, B.; Singh, P. The current and future states of Ethiopia's energy sector and potential for green energy: A comprehensive study. Int. J. Eng. Res. Afr. 2017, 33, 115-119. [CrossRef]

23. National Planning Commission of Ethiopia. Ethiopia 2017 Voluntary National Review on SDGs: Government Commitments, National Ownership and Performance Trends. Available online: https:/ /www.undp.org/content/dam/ethiopia/docs/2017 /The2017VNRsonSDGs_Ethiopia(Eng)Webversion.pdf (accessed on 15 September 2021).

24. MOFED-Ethiopia. Growth and Transformation plan-I (GTP I)- 2010/11-2014/2015. Available online: https://www. greengrowthknowledge.org/national-documents/ethiopia-growth-and-transformation-plan-i (accessed on 10 June 2019).

25. National Planning Commission of Ethiopia. Growth and Transformation Plan II (GTP II) (2015/16-2019/20). Volume I. Available online: https://www.greengrowthknowledge.org/national-documents/ethiopia-growth-and-transformation-plan-ii-gtp-ii (accessed on 15 September 2021).

26. National Planning Commission of Ethiopia. Ethiopia 2030: The Pathway to Prosperity. Available online: https:/ phe-ethiopia org/wp-content/uploads/2021/04/10_year_plan_english_final.pdf (accessed on 5 May 2021).

27. Maasho, A. Ethiopia Trash Dump Landslide Death Toll Rises to 115. Available online: https://www.reuters.com/article/usethiopia-accident/ethiopia-trash-dump-landslide-death-toll-rises-to-115-idUSKBN16N0NR (accessed on 21 September 2020).

28. Cambridge Industries Energy. Africa's First Waste-to-Energy Facility. Available online: https://static1.squarespace.com/static/ 57c7f80620099eafefefe77a/t/5b31caeff950b7cb65f7437d/1529989903242/Reppi+Brochure+\%28technical+detail\%29.pdf (accessed on 12 October 2020).

29. Alemayehu, S. Case Study: Developing Waste-to-Energy in Africa. Available online: https://worldwastetoenergy.com/wpcontent/uploads/2019/05/Samuel-Alemayehu-Cambridge-Industries.pdf (accessed on 7 October 2020).

30. Hailu, A.D.; Kumsa, D.K. Ethiopia renewable energy potentials and current state. AIMS Energy 2020, 9, 1-14. [CrossRef]

31. Asfaw, A. Sustainable Household Energy for Addis Ababa, Ethiopia. J. Sustain. Dev. 2012, 8, 1-11.

32. Ambelu, A.; Lock, K.; Goethals, P.L.M. Hydrological and anthropogenic influence in the gilgel gibe i reservoir (Ethiopia) on macroinvertebrate assemblages. Lake Reserv. Manag. 2013, 29, 143-150. [CrossRef]

33. Demissie, T.A.; Saathof, F.; Selesh, Y.; Gebissa, A. Evaluating the Effectiveness of Best Management Practices in Gilgel Gibe Basin Watershed-Ethiopia. J. Civ. Eng. Archit. 2013, 7, 1240-1252. [CrossRef]

34. Bank, W. AFRI RI-The Eastern Electricity Highway Project under the First Phase of the Eastern Africa Power Integration Program; World Bank: Washington, DC, USA, 2013.

35. International Rivers. The Grand Ethiopian Renaissance Dam Fact Sheet. Available online: https://archive.internationalrivers. $\mathrm{org} /$ resources / the-grand-ethiopian-renaissance-dam-fact-sheet-8213 (accessed on 15 September 2021).

36. Whittington, D.; Waterbury, J.; Jeuland, M. The grand renaissance dam and prospects for cooperation on the eastern nile. Water Policy 2014, 16, 595-608. [CrossRef]

37. Abdelhady, D.; Aggestam, K.; Andersson, D.-E.; Beckman, O.; Berndtsson, R.; Palmgren, K.B.; Madani, K.; Ozkirimli, U.; Persson, K.M.; Pilesjö, P. The Nile and the Grand Ethiopian Renaissance Dam: Is There a Meeting Point between Nationalism and Hydrosolidarity? J. Contemp. Water Res. Educ. 2015, 155, 73-82. [CrossRef]

38. MoWIE-Ethiopia. Highlights of the Grand Ethiopian Renaissance Dam \& Regional Interconnection. Available online: https:// au.int/sites / default/ files / documents /36067-doc-ethiopian_energy_sector_highlight_lome_togo_december_2017_final.pdf (accessed on 27 November 2020).

39. US Foreign Commercial Service. ETHIOPIA: Power Sector Market, Ethiopia Statistics. Available online: https:/ / rise.esmap.org/ data/files/library/ethiopia/EthiopiaPowerSectorMarketOverviewUS.pdf (accessed on 29 November 2020).

40. Howell, J. Rural Electrification \& Renewable Energy in Ethiopia. Available online: http:/ / web.colby.edu/eastafricaupdate/files / 2012/02/Environmental-Policy-Review-2011_Chapter-6_color_small.pdf (accessed on 15 September 2021).

41. Howells, M.; Rogner, H.H.; Mentis, D.; Broad, O. Energy Access and Electricity Planning; World Bank: Washington, DC, USA, 2017.

42. Kaygusuz, K. Energy for sustainable development: A case of developing countries. Renew. Sustain. Energy Rev. 2012, 16, 1116-1126. [CrossRef]

43. Geissler, S.; Hagauer, D.; Horst, A.; Krause, M.; Sutcliffe, P. Biomass Energy Strategy for Ethiopia; European Union Energy Initiative: Eschborn, Germany, 2013; Volume 41.

44. Gabisa, E.W.; Gheewala, S.H. Potential of bio-energy production in Ethiopia based on available biomass residues. Biomass Bioenergy 2018, 111, 77-87. [CrossRef]

45. Tucho, G.T.; Nonhebel, S. Alternative energy supply system to a rural village in Ethiopia. Energy. Sustain. Soc. 2017, 7. [CrossRef]

46. UNEP; African Union. Review of Woodfuel Biomass Production and Utilization in Africa: A Desk Study. Available online: https: / / wedocs.unep.org/handle/20.500.11822/28515 (accessed on 7 January 2021).

47. Burnside, N.; Montcoudiol, N.; Becker, K.; Lewi, E. Geothermal energy resources in Ethiopia: Status review and insights from hydrochemistry of surface and groundwaters. WIREs Water 2021, 149, 161-172. [CrossRef] 
48. Bekele, B.; Ugo, Y.; Chauhan, R. Assessment of Fuel Wood Energy Demand of Arba Minch Town, GamoGofa Zone, Southern Ethiopia. Int. J. Bioresour. Stress Manag. 2021, 12, 89-94. [CrossRef]

49. Kiplagat, J.K.; Wang, R.Z.; Li, T.X. Renewable energy in Kenya: Resource potential and status of exploitation. Renew. Sustain. Energy Rev. 2011, 15, 2960-2973. [CrossRef]

50. Alem, S.; Duraisamy, J.; Legesse, E.; Seboka, Y.; Mitiku, E. Wood charcoal supply to Addis Ababa city and its effect on the environment. Energy Environ. 2010, 21, 601-609. [CrossRef]

51. Kyriakopoulos, G.; Kolovos, K.G.; Chalikias, M.S. Environmental sustainability and financial feasibility evaluation of woodfuel biomass used for a potential replacement of conventional space heating sources. Part II: A combined Greek and the nearby Balkan countries case study. Oper. Res. 2010, 10, 57-69. [CrossRef]

52. Kyriakopoulos, G.L.; Kolovos, K.G.; Chalikias, M.S. Woodfuels Prosperity towards a More Sustainable Energy Production. In Knowledge Management, Information Systems, E-Learning, and Sustainability Research, Proceedings of the Third World Summit on the Knowledge Society Part I, WSKS 2010, Corfu, Greece, 22-24 September 2010; Lytras, M.D., Pablos, P.O., De Ziderman, A., Roulstone, A., Maurer, H., Imber, J.B., Eds.; Springer: Berlin/Heidelberg, Germany, 2010; Volume 112, pp. 19-25, ISBN 978-3-642-16323-4.

53. Mengistu, A.T. Modeling and Analysis of Long-Term Shifts in Bioenergy Use (With Special Reference to Ethiopia). Available online: www.diva-portal.org/smash/record.jsf?pid=diva2:652857 (accessed on 5 January 2021).

54. Alemayehu, Y.A. Status and benefits of renewable energy technologies in the rural areas of ethiopia: A case study on improved cooking stoves and biogas technologies. Int. J. Renew. Energy Dev. 2015, 4, 103-111. [CrossRef]

55. Teshome, F.B. Municipal solid waste management in Ethiopia; the gaps and ways for improvement. J. Mater. Cycles Waste Manag. 2021, 23, 18-31. [CrossRef]

56. Yu, Y.; Yu, Z.; Sun, P.; Lin, B.; Li, L.; Wang, Z.; Ma, R.; Xiang, M.; Li, H.; Guo, S. Effects of ambient air pollution from municipal solid waste landfill on children's non-specific immunity and respiratory health. Environ. Pollut. 2018, 236, 382-390. [CrossRef]

57. Mohammed, A.; Elias, E.; Science, E.; Ababa, A. Solid waste management environmental impacts in Addis Ababa city. J. Environ. Waste Manag. 2017, 4, 194-203.

58. Yimam, Y.M.; Tesfaye, N. Environmental and Health Impacts of and Challenges on RappieKoshe Waste-to-Energy Facility, Addis Ababa. Int. Res. J. Multidiscip. Scope 2020, 1, 9-17. [CrossRef]

59. Hamza, T.A.; Alebjo, A.L. Sugarcane SaccharumOfficinarum L Tissue Culture In Ethiopia Opportunities For Ethiopias Sugar Industries. Int. J. Sci. Technol. Res. 2017, 6, 398-406.

60. Girma, Z. Challenge and opportunities on energy provision and rural electrification in Ethiopia. Int. J. Renew. Energy Technol. 2016, 7, 184. [CrossRef]

61. Bekele, G.; Palm, B. Feasibility study for a standalone solar-wind-based hybrid energy system for application in Ethiopia. Appl. Energy 2010, 87, 487-495. [CrossRef]

62. Power, M.; Shanko, M.; IES; Hankins, M.; Saini, A.; Kirai, P. Target Market Analysis: Ethiopia's Solar Energy Market; Deutsche Gesellschaft für Technische Zusammenarbeit (GTZ) GmbH: Berlin, Germany, 2009.

63. Kebede, K.Y.; Mitsufuji, T. Technological innovation system building for diffusion of renewable energy technology: A case of solar PV systems in Ethiopia. Technol. Forecast. Soc. Chang. 2017, 114, 242-253. [CrossRef]

64. IEA. Renewable Energy Policy Update. Available online: http://www.renewableenergyworld.com/rea/news/article/2010/07/ renewable-energy-policy-update-for-china (accessed on 16 February 2020).

65. (GSE) Geological Survey of Ethiopia. Formulating Master Plan on Development of Ethiopia. Available online: http://open_ jicareport.jica.go.jp/pdf/12233185_01.pdf (accessed on 19 December 2020).

66. Guangul, F.M.; Chala, G.T. Geothermal Power Potential in Ethiopia. In Clean Energy Opportunities in Tropical Countries; Sulaiman, S.A., Ed.; Springer Nature: Singapore, 2021; pp. 197-216, ISBN 9789811591396.

67. Alvarez-Silva, O.A.; Osorio, A.F.; Winter, C. Practical global salinity gradient energy potential. Renew. Sustain. Energy Rev. 2016, 60,1387-1395. [CrossRef]

68. Tufa, R.A.; Pawlowski, S.; Veerman, J.; Bouzek, K.; Fontananova, E.; Di Profio, G.; Velizarov, S.; Goulão Crespo, J.; Nijmeijer, K.; Curcio, E. Progress and prospects in reverse electrodialysis for salinity gradient energy conversion and storage. Appl. Energy 2018, 225, 290-331. [CrossRef]

69. Schaetzle, O.; Buisman, C.J.N. Salinity Gradient Energy: Current State and New Trends. Engineering 2015, 1, 164-166. [CrossRef]

70. Tufa, R.A.; Curcio, E.; Fontananova, E.; Di Profio, G. Membrane-Based Processes for Sustainable Power Generation Using Water: Pressure-Retarded Osmosis (PRO), Reverse Electrodialysis (RED), and Capacitive Mixing (CAPMIX). In Reference Module in Chemistry, Molecular Sciences and Chemical Engineering; Elsevier: Amsterdam, The Netherland, 2017; ISBN 9780124095472.

71. Alvarez-Silva, O.; Winter, C.; Osorio, A.F. Salinity Gradient Energy at River Mouths. Environ. Sci. Technol. Lett. 2014, 10, 410-415. [CrossRef]

72. Yip, N.Y.; Brogioli, D.; Hamelers, H.V.M.; Nijmeijer, K. Salinity gradients for sustainable energy: Primer, progress, and prospects Environ. Sci. Technol. 2016, 50, 12072-12094. [CrossRef]

73. Mei, Y.; Tang, C.Y. Recent developments and future perspectives of reverse electrodialysis technology: A review. Desalination 2018, 425, 156-174. [CrossRef]

74. Miller, H.A.; Bouzek, K.; Hnat, J.; Loos, S.; Bernäcker, C.I.; Weißgärber, T.; Röntzsch, L.; Meier-Haack, J. Green hydrogen from anion exchange membrane water electrolysis: A review of recent developments in critical materials and operating conditions. Sustain. Energy Fuels 2020, 4, 2114-2133. [CrossRef] 
75. Ni, M.; Leung, D.Y.C.; Leung, M.K.H.; Sumathy, K. An overview of hydrogen production from biomass. Fuel Process. Technol. 2006, 87, 461-472. [CrossRef]

76. Levin, D.B.; Chahine, R. Challenges for renewable hydrogen production from biomass. Int. J. Hydrogen Energy 2010, 35, 4962-4969. [CrossRef]

77. Worede Fantaye Hailemariam. The Challenges of Renewable Energy Resource Development: The Case of Gilgel Gibe III Hydropower Project in Ethiopia. Available online: https://www.duo.uio.no/bitstream/handle/10852/32612/MPhil-ThesisThexChallengesxofxRenewablexEnergyxResourcexDeviopment-ThexCasexofxGilgelxGibexIIIxHydropowerxProjectxinxEthiopia. pdf\%3Fsequence\%3D1 (accessed on 21 February 2021).

78. Regassa, N.; Sundaraa, R.D.; Seboka, B.B. Challenges and Opportunities in Municipal Solid Waste Management: The Case of Addis Ababa City, Central Ethiopia. J. Hum. Ecol. 2011, 33, 179-190. [CrossRef]

79. Gebreslassie, M.G. Development and manufacturing of solar and wind energy technologies in Ethiopia: Challenges and policy implications. Renew. Energy 2021, 168, 107-118. [CrossRef] 